\title{
Old Pedagogies for Wise Education: A Janussian Reflection on Universities
}

\author{
Zane M. Diamond
}

check for

updates

Citation: Diamond, Z.M. Old Pedagogies for Wise Education: A Janussian Reflection on Universities. Philosophies 2021, 6, 64. https:// doi.org/10.3390/philosophies6030064

Academic Editor: Nicholas Maxwell

Received: 7 May 2021

Accepted: 16 July 2021

Published: 3 August 2021

Publisher's Note: MDPI stays neutral with regard to jurisdictional claims in published maps and institutional affiliations.

Copyright: (C) 2021 by the author. Licensee MDPI, Basel, Switzerland. This article is an open access article distributed under the terms and conditions of the Creative Commons Attribution (CC BY) license (https:/ / creativecommons.org/licenses/by/ $4.0 /)$.
School of Education, Culture \& Society, Faculty of Education, Monash University, Clayton, VIC 3800, Australia; zane.diamond@monash.edu

\begin{abstract}
This paper presents a synthesis of time-honoured pedagogical approaches to develop wisdom suitable to address the urgent problem-solving requirement of the modern university. During these last 30 years, I have employed a range of critical, interpretivist, qualitative research methods to examine archival and archaeological evidence and conduct cross-cultural and often comparative and international case studies to study wisdom. My central concern has been to understand how teachers across diverse locations throughout history have learned to develop wisdom and how they have educated others to such understandings. As part of this work, I examined the modern university and its capacity to engage with local knowledge and wisdom. Over the course of analysis, I find that one of the constraints of scaling up institutions for learning wisdom into the now global model of the university is that universities have forgotten how to develop wisdom in the race towards industrialisation, colonisation, and neo-liberalism within the scientific paradigm. One of the early sacrifices of such scaling up was the ability of the university to preserve an intention to develop the wisdom of its students. Therefore, distant memory now is the ideation of wisdom that many societies and civilisations, and their institutions of higher learning, are in danger of forgetting the pedagogical pathway to do so. The paper begins with an examination of the long history of pedagogies for the development of wisdom. I then briefly discuss the methodological aspects of this paper and explain my key terms: information, knowledge and wisdom, followed by an examination of wisdom through the lens of the teaching and learning modalities of the Oral, Written, and Printing. My synthesis of wisdom artefacts and stories about pedagogy suggests that while wisdom is individually sensed, understood, and lived phenomenologically, its meaning is latent, socially agreed, and constrained in terms of how and if universities might cultivate its essential elements. Taking a Janussian backwardand forward-looking view, I propose a remembering and reconnecting approach to educating for wisdom through purposeful consideration of what we know about time-honoured pedagogies for teaching and learning wisdom, what are its current constraints, and what are its future opportunities in the university into the new postmodern, planetary, virtual education era.
\end{abstract}

Keywords: wisdom; pedagogy; university; worldly wisdom; teaching and learning modalities; wisdom pedagogy; domains of knowledge; balance pedagogies

\section{Introduction}

The concept of wisdom in human ideation can be traced back through oral histories, archaeological evidence, literature, and the internet to the end of the most recent Ice Age and beyond. From the synthesis of these materials, it becomes clear that individual humans are capable of having, experiencing, and developing wisdom as communicated by them to other humans. Over time, and in diverse civilisations, individual humans have shared their knowledge and experiences of developing their wisdom. Through forms of education using different modalities, some of these insights and practices become cultural habits and inclinations and have even gone on to form spiritual, religious, philosophical, and ideological traditions. As I elaborate, the development of wisdom has been approached using two lenses: what is variously understood as practical, problem-solving, worldly 
wisdom, and that which concerns itself with what might be called transcendental or higher wisdom. Over millennia, humans have created teaching and learning practices and institutions to develop one or both.

The ideas presented in this paper derive from my research into the concept of wisdom spanning more than 30 years. I employed a range of critical, interpretivist, qualitative research methods to examine archival and archaeological evidence and conduct crosscultural and often comparative and international case studies to study wisdom. My synthesis of many types of data about wisdom allows me, in this paper, to offer a Janussian reflection on some of the vital pedagogical elements of wisdom development and what might be usefully carried from the past into the future university.

Since the end of the last Ice Age, approximately 12,500 years ago, humanity has learned to speak, communicate, write, read, and develop books, printing presses, and now the virtual world of the internet as transmission methods of our ideas. My analysis of stories and extant materials leads me to suggest that while there have been significant changes in teaching and learning modalities throughout this time, there has been a thread of human transmission of ideas about developing wisdom through education.

Of importance to acknowledge first in this paper, the idea of wisdom and from where and how it arises has been argued among humans for thousands of years. The initial arising in a human mind of a concept such as wisdom can never be attributed a precise date, person, or location for its beginning. I give the end of the last Ice Age as a marker of the development of oral forms of communication among humans and thereby assume that the concept of wisdom began forming and being communicated during this time. In presenting this long view, looking back into the history of the idea of wisdom and its pedagogies, I make an apology for what might sometimes appear as being too generalised to be of any use. As many scholars are, I am challenged by the risk of glossing over seemingly incommensurable aspects of the topic in pursuit of the "grand narrative" that was rightly challenged by Lyotard [1]. While he noted that grand theories of the world were unable to reflect the nuance of a topic sufficiently to be of use, his critique was specifically questioning the authority of the grand narrative. In the ensuing 40 years, theoreticians of the postmodern have significantly influenced my thinking about wisdom as a topic. There have been many debates across the humanities and social sciences about presenting an overview of a topic without epistemic violence to people, cultures, and lifeways. The work of Connelly and Clandinin [2-4] with others has been influential in my approach to the study of wisdom in education, employing narrative inquiry to examine many "small stories" to help build an inductive, more extensive picture of people's understandings about how to develop a latent human potential such as wisdom.

As discussed more fully in a later section, one of the many methodological issues I have addressed has been making sure that my studies of wisdom and its pedagogies have not been first-world-centric. From the outset, I have worked to ensure that my data collection and analysis are not only about the people of the global North and their stories, of those living in the metropoles who have controlled the means of production of ideas since the advent of the printing presses. It has taken me considerable time, together with the willingness of people from diverse traditions to share their stories, for me to develop this Janussian analysis that is respectful of many viewpoints looking back to enable universities to move forward into a postmodern formation that is more considered and inclusive, in a socially-just manner.

As we move into a new education era where teaching and learning modalities might more likely be online, via the internet in a virtual mode, scholars of the global South are arguing for the need to decolonise universities (see, for example, Dei [5]), questioning the move towards the virtual at a time when many communities still struggle with access to the internet and to technological equipment that is needed to do so. It is precisely into this space of future possibilities and inequities that my Janussian analysis speaks, where time-honoured pedagogies for wisdom development may address many of the demands of marginalised peoples for their views and lifeways to be included in the future planetary 
development of humanity and its potentiality to create a wise future for children and all sentient beings. The postmodern university will remember and reconnect with storehouses of human knowledge about the pedagogies to develop wisdom for problem-solving and self-improvement by including these old methods.

Worthy of note and posing a challenge to contemporary scholarship about and methodologies that study wisdom, my analysis suggests that the motivation to develop wisdom arises within individuals, subject to their inclination. Most people who have spoken to me over many years, from diverse backgrounds, report having had formative experiences or posed questions that could not be answered by their family, community, school teacher, lecturer, or spiritual guide. Defying propositions that wisdom is socially constructed and that the "we" always precedes the "I", many individuals spoke of living at a counterpoint with their families and peers from a young age, reporting that they always felt different. I began to understand that there is something to explore, in that they are "I before we" people, and in seeking answers, they have been drawn to one of the many wisdom paths.

They commonly sought out someone or some extant text that they thought might explain their ideas or experiences and help them with their development process. Beyond the scope of this small paper, I suggest that there is a need for consideration of an autochthonous potentiality for the development of wisdom that does not necessarily have $a$ priori existence in society. For the individual who wants to develop their wisdom, whether this is to develop their wise leadership, problem-solving, or political acumen skills or their transcendent understanding of wisdom, they may stumble onto a self-development website, choose a course of study at university, or simply live in an environment where the pursuit of wisdom is discussed and given importance. It seems that once an individual apprehends the motivation to develop wisdom, there have been teachers, guides, gurus, life coaches, and bodies of knowledge and institutions that have existed, some that continue to exist, to support such education.

The bigger question might be whether it is possible to activate the curiosity in students to develop wisdom through the education system when they do not come from an individual inclination or a family or community with an inclination towards self-development. For the most part, this paper assumes that the development of wisdom is possible through purposeful pedagogies and will concern itself with the question of what effective pedagogies for the development of wisdom can be brought into the university as it makes a significant transition into the world of virtual teaching and learning. I would argue that as we enter the new virtual education era, ancient bodies of knowledge are worthy of reconsideration to help humanity remember what it has forgotten as universities struggle to find relevance in solving seemingly insoluble problems.

\section{The University, Education, and the Concept of Higher Learning}

In the education literature, the discussion about wisdom is tentative but is slowly surfacing. Nabobo [6] and Teasdale and Little [7] initiated discussing the relationship between education and culture. Some of the papers in this collection specifically investigated wisdom and knowledge (Kopong [8], Ma Rhea [9], Mel [10], Nabobo and Teasdale [11], and Thaman [12]) in various national, cultural settings. This edited collection approaches the study of the development of wisdom from the broad field of cross-cultural expressions of its manifestation. In the collection Local Knowledge and Wisdom in Higher Education (Teasdale and Ma Rhea [13]), the authors who contributed to this edited collection expanded the work to investigate different cultural contexts and the influence of culture on how wisdom traditions are being preserved in universities. An impressive and growing body of work is also emerging online that asks what educational processes can help students become wiser (see, for example, the page Education for Wisdom http:/ / www.wisdompage.com/ed4wis00.html, accessed on 26 July 2021). In keeping with my broader analysis, some of this vital work is being conducted outside universities. This work becomes understandable when considering some of the issues confronting teachers and researchers of wisdom in the higher education sector. 
The idea of the university has developed and changed over time and in geographical location. One of its consistent claims has been that of the search for truth based on evidence. In the most recent form of the university, the search for evidence-based truth co-exists with its broader functional aims. For this paper, the critical point to note is that were the precursors to the modern university in places such as Nalanda, India (c. $2564 \mathrm{BE}$; 2220 years ago), the Yuelu Academy, Changsha, Hunan, China (c. 1045 years ago), and in northern African examples such as the Al-Azhar University, Cairo, Egypt (c. AH 359; 1501 years ago) and the University of al-Qarawiyyin in Fez, Morocco (c. 1162 years ago). By the twelfth century, scholars (possibly the original international students) travelled great distances to be accepted to study in these well-established centres of learning. The modern university form, greatly influenced by the European universities of the twelfth to sixteenth centuries (le Goff [14]), now attracts international students from those early centres of learning, emphasising the significant shift in the sorts of information and types of qualifications that have become desirable and, therefore, marketable.

A working definition of a university as recorded in the Oxford English Dictionary [15] (p. 3493) is:

... a corporation of teachers and students formed for the purpose of giving and receiving instruction in a fixed range of subjects beyond that provided at a school. Later, an institution of higher education, offering courses and research facilities in mainly nonvocational subjects and having acknowledged powers and privileges, especially that of conferring degrees...

This modern definition of a university obscures the complexities by which a university exists in the first place as an institution of higher learning. There is a much older history of the concept of higher learning that finds a place for the development of wisdom that is civilisational and speaks to a long history of education eras. While the idea of "higher" learning seems to have been lost in the turn towards worldly enlightenment through science and more recent neo-liberal massification and democratisation of universities, the need to cultivate wisdom has not gone away.

Many ancient civilisations developed centres of higher learning to cater to people's interest in cultivating their wisdom. In one of the oldest examples of a university, Nalanda, that continues today in a significantly more modern form and with new buildings (Banerjee [16]; Krishnan [17]), the aim was to gather scholars interested in the development of wisdom. Some were inclined to philosophy, while some provided opportunities for students to practice techniques for wisdom development and engage in discussion with experts and scholars. There was a range of curricula that were described by Chinese scholars such as Faxian (see Bhikkhu Ānandajoti [18]; c. 1622 years ago) and Xuanzang (also known as Hiuen-Tsiang; Hwui-li and Beal [19]; Xuanzang [20]). Nalanda was an established place of higher learning that was a meeting place for discussions between teachers who held different views on the nature of the pathway to spiritual development and wisdom for Brahmins, Jains, and the Buddha and their respective followers. In the reverse of today's universities, people learned their trade or profession from guilds and family members and attended universities for higher learning.

My metasynthesis and analysis find that the role of the university has been rewritten. It is less about higher learning and is now being made accessible to a broader audience, revolutionising its earlier focus on developing higher consciousness and wisdom and demanding that university knowledge be marketable and responsive to more significant economic initiatives. As the Role of Higher Education in Promoting Education for All (UNESCO [21] (p. 12) report says:

As higher education moves from an elite to mass universal system of participation, it involves directly, or touches upon the lives of increasing proportions of the population of each country and is called upon to perform an expanding range of tasks.

It is clear to me that new efforts by scholars such as Maxwell, Nabobo, Thaman, Dei, Teasdale, Kopong, Sternberg, and Mel, among others, to promote the idea of wisdom 
development and to argue for its study and practice as the core business of universities as institutions of higher learning will fail unless the development of wisdom becomes part of what is measured in global university ranking assessments. Universities will need to reach further back in human evolution to move forward again; such is the almost total absence of interest in the topic in the contemporary form. Nor is there an institutional memory of how to teach nor global ranking pressure to drive such a development.

While scholars from the global South argue for the decolonisation of the western biases in the modern, global university, scholars of the global North have lamented the changes in the institutions of higher learning that had developed over centuries before the period of industrialisation and colonial expansion. In the European context, Comte [22] argued that higher learning in his era was marginalised and trivialised under the influence of positive science. Ancient Chinese academies of higher learning, established during the Han era (c. 124 BC), taught Confucianism. Like European and Middle Eastern universities, the focus was on studying literature, religious thought, and classic philosophy. In China, this approach continued into the Qing Dynasty (c. 1600-1912). Defeated in war during the period of European and English colonisation, China responded to its lack of knowledge of western scientific advances by establishing its first university, National Peiyang University (北洋大学堂), based on the American model with a focus on engineering. During the most recent colonial period, the impact of global territorial aggressions was that many nationstates in the late 1800s and early 1900s tasked their institutions of higher learning with more pragmatic concerns such as the development of military capability, infrastructure, and competitive economies on a global scale.

Over these past 200 years, there has been an increasingly strong emphasis placed on practical problem-solving in universities for the benefit of society as a whole rather than through the development of the individual character of each student. In what has become the scientific approach to problem-solving, what is known is provisional knowledge until it is proven false. A crisis hits an economy; finite resources run out; we experience a pandemic that kills millions across the planet; and people begin a search for answers to questions for which they do not have the skills, knowledge, or understanding to navigate. In the new model of the university, students have been educated to solve any crisis facing humanity through research and operationalisation of solutions based on evidence. Lacking an ongoing focus on their personal development, students have also come to expect a world where everything functions as it is supposed to, and if it fails to work, it can be fixed. This failure of highly educated people to have the necessary life skills to cope with situations that cannot be fixed quickly is characteristic of the current education era. We fail to teach the basics of problem-solving that are a foundational element in skill development towards wisdom. This weakness was noted by Carl Rogers [23] in Towards a Theory of Creativity, where he observed that there is an urgent social need because:

With scientific discovery and invention proceeding, we are told, at a rate of geometric progress, a generally passive and culture-bound people cannot cope with multiplying issues and problems. Unless individuals can imagine, construct and creatively revise new ways of relating to these complex changes, the lights will go out.

(Rogers [23] p. 348)

Scholars in universities in various branches of psychology, neurobiology, philosophy, education, and the social sciences, under the sustained leadership of scholars such as Robert J. Sternberg in psychology (see, for example, Sternberg [24]; Sternberg and Glück [25]) and philosopher Nicholas Maxwell [26-30] have been working to re-establish the development of wisdom as a credible field of scholarship within the modern university and across domain ontologies. Their efforts have faced resistance because the work is being conducted in a university environment that has focused on pursuing the ways of knowing that arises from a particular historical formation of industrialisation, colonisation, and more recent forms of neo-liberalism driven by the approach to problem-solving using the scientific approach. Scholars such as Horkheimer and Adorno [31] examined this turn away from 
the Enlightenment principles and the loss of reason but pessimistically could offer no ideas about re-establishing reason.

While frustratingly slow to be recognised, the efforts of Sternberg, Maxwell, Thaman, Dei, and others align more closely to the aspiration of Enlightenment thinking in their appeal towards reason and older wisdom-developing pedagogies and methods of ancient civilisations than the current university allows for, or even remembers. The rapid retasking of universities across the globe during the late 1800s and through the 1900s towards practical problem solving is now recognised as being unbalanced because it relies on a particular version of scientific reason to solve the increasingly overwhelming problems that humans have created (Bhaskar [32]).

Contemporary universities, like all global institutions, are experiencing significant transformation. Indeed, the COVID-19 global pandemic has hastened this transformation, but it did not cause it. What is driving the re-shaping of universities is two-fold: first, we are moving into a new planetary education era where the methods by which human knowledge has been gathered and passed on between generations is undergoing fundamental transformation; second, in its current form, universities are becoming no longer fit for purpose because the society around them needs different solutions to wicked problems to those currently being offered. I will argue in this paper that the concept and operationalisation of the current formation of higher learning, the university, was born out of the industrial colonial age, which was only one relatively short but highly influential education era that has shaped education along a path in the development of human knowledge and its transmission. The outmoded, unsustainable, industrial, colonial mindset that is so dominant in the modern university was developed by the same mindset that oversaw the development of modern science and made sense of the "discovery" of the New World (Ma Rhea [33]). I place the idea of discovery in quote marks to emphasise that for the people living on "discovered" lands, they already knew where they were and who they were and did not even realise they were being discovered until they understood how they were being fitted into a new global story (Ma Rhea and Teasdale [34]).

The modern university tends to re-create this story. The young professionals with whom I work, future teachers and academics in schools and universities need a different set of skills, knowledge, and understanding akin to what Scheler [35] (p. 164) argued:

... religion, metaphysics and positive science are different from one another by essence and ... are all genuine basic properties of the human mind. As a practical demand concerning the construction of organisations of education in the various nations, it follows that in such construction, there should not be one-sided training in the direction of any one of these forms of knowledge but a harmonious training in all of them.

This observation certainly resonates with the needs of future professionals who will become societal leaders as they learn to respond to the significant, wicked challenges they will face in their working lives. The challenges they face cannot be solved by singular approaches but will require innovative, complex, and fresh solutions arising from them learning how to work with different ways of knowing (Taylor and Pacini-Ketchabaw [36]). Governments and their tax-paying citizenry that are funding the tertiary education sector across the globe are demanding that universities change but do not seem to provide a future approach to higher learning that is anything but more of the same but at less cost.

A watershed report, Our Common Future (Brundtland Report) (World Commission on Environment and Development [37]), located the work of education and higher education, particularly within the significant global challenges facing humanity into the twentyfirst century. As I have noted in previous research (Ma Rhea [38-40]), universities are encouraging particular ways of knowing, such as scientific reasoning, that have high status but appear limited in their effectiveness and usefulness without additional perspectives and types of reasoning. As Toffler [41] says in his book, Future Shock (p. 12):

... Earnest intellectuals talk bravely about "educating for change" or "preparing people for the future". But we know virtually nothing about how to do it. In the most rapidly 
changing environment to which people have ever been exposed, we remain pitifully ignorant of how the human animal copes.

As I noted regarding Australia's bilateral university exchange relationship with Thailand (Diamond [40]), the last 70 years has witnessed that the university system has spread a particular way of thinking and knowing and is creating a mindset that shapes our responses to the future (Clarke [42]). This approach exponentially restricts students' latent potential in higher learning institutions such as universities across the planet who need to be taught to develop a more sophisticated, complex way of knowing, such as that proposed by scholars of wisdom. I argue that the cognitive epistemological scientific reasoning mindset, with its unbalanced focus on generating information, produces many of the problems that we experience. The work by wisdom scholars offers the potential to develop a broader conception of domains of knowledge that enable integration of axiological and ontological domains of knowing into higher education now that society is beginning to see the limits of the sole focus of universities being about information generation and accumulation.

For most universities, there is little to motivate senior leadership to change their approach while the model still has so much ability to attract money for what it does. These universities, as degree-granting organisations that credentialise the next generation of professionals and leaders across the globe, have been criticised for becoming degree machines under the pressures of neo-liberalism that see universities as quasi businesses that are required to compete in the market for funds for teaching and research (Dore [43]). As will be examined later in this paper, the critique of the gradual privatisation of higher learning might be a distraction to the central issue because even a cursory examination of the history of the development of centres of higher learning shows that many were established and funded by a private endowment in civilisations such as Egypt, MesoAmerica, Mesopotamia, Greece, India, and China, and the study of the development of wisdom was an essential element of such an education. People were willing to pay for such an education. In the contemporary era, it would appear that the critique of neo-liberalism may be misplaced in consideration of wisdom. Neo-liberalism drives profit motivation. While some regard neoliberalism and capitalism more broadly as undermining wisdom (Smith [44]), I argue here that universities and their global ranking systems need only to focus on the cultivation of wisdom as being teachable, marketable, and not in competition with the accumulation of information and a credentialing degree for human ingenuity to once again restore ancient practices of wisdom development to the forefront.

The potentiality for universities to embrace this work is strengthened by findings of my analysis that reveal that people are willing to pay for access to information about developing their wisdom via the internet and in places of learning outside of universities. Why is this not occurring in universities? Critics of neo-liberalist impacts on universities need to examine such cross-currents and turbulences. My research has engaged with many people who work both inside and outside academia, for example, Indigenous peoples, sustainability ecologists, and other aligned activists, who recognise the opportunity within the work of universities to support and encourage the development of wisdom. Such people might also work outside the formal, nationally, and privately funded degree conferring universities, often frustrated by the resistance to incorporating wisdom into their work. For example, independent academic Copthorne Macdonald, in his ground-breaking work in the early 1990s (http: / / www.wisdompage.com/, accessed on 26 July 2021), began in mapping out the idea of wisdom through using the internet and inviting wisdom scholars to collaborate in this exciting space of opportunity to study and promote the teaching of the skills of wisdom development. His approach to using the internet and bypassing the "bricks and mortar" universities heralds a new education era to be examined more closely in a later section of this paper. This significant body of work, continued by scholars such as Nicholas Maxwell, Leland R. Beaumont (https: / thewisepath.org/, accessed on 26 July 2021), and Tom Lombard, highlights the importance of new technologies in supporting new insights, approaches, and possibilities being canvassed in such truly global endeavours. Remarkably, within the modern university, only a small number of academic disciplines have carried 
the torch for wisdom studies, as evidenced by the scope of the recent Cambridge Handbook of Wisdom (Sternberg and Glück [25]), and specific scholarly field such as philosophy (see, for example, Kane [45]), the psychological and cognitive sciences (see, for example, Ardelt [46,47]; Sternberg [48]; Sternberg and Jordan [49]), and education-focused work such as found in Hattam [50], Steel [51], and Smith [44] and edited collections such as Ferrari and Westrate [52] and Teasdale and Ma Rhea [13].

An overarching argument in favour of universities changing their fundamental approach from knowledge inquiry to wisdom inquiry methods has been made by Nicholas Maxwell [26,27,53-55] in his most recent work and the Friends of Wisdom group under his leadership, emphasising a crisis in the university sector about what sorts of knowledge it is producing and how it is producing it, arguing that there has been little heed of, but the significant need for, the idea of the cultivation of wisdom as part of core university business. One might expect to see wisdom given an important place in the current Graduate Attribute aspirational list for a professional university qualification. One might also expect that education faculties and executive leadership development programs might aspire to educate a wise citizenry.

Yet, the study of wisdom does not seem to be marketable. Alas, my research and that of others suggest that the development of wisdom remains largely absent from most aspects of the university core business, impacted by a fear that potential students will not spend money going to a university to develop their wisdom but failing to test the market with their significant capacity to influence and drive market reform. Many university administrators have told me over the years that the development of wisdom is far more likely to occur through the volunteering and extracurricular activities undertaken by students during their degrees (Diamond [40]). I meet many professional and future leaders of societies worldwide who have no understanding of different ways of knowing, no motivation or recognised need for them to develop their wisdom, and no framework by which to do so. I argue that this absence of a perception of need in an individual speaks to the more significant matter of what humanity has lost in its rapid scaling up of mass higher education to address practical problems. It has forgotten the importance of the development of wisdom and its pedagogies.

In teaching and teacher education, scholars such as Beare and Slaughter [56], Semetsky and Delpech-Ramey [57], Steel [51], Furman [58], and Lunenberg and Korthagen [59] encourage the need to develop wisdom in students. They pose questions that ask how we are to educate people for the future and the purpose of education. Beare and Slaughter speak of the need for a new global consciousness and particularly identify the need to go beyond scientific rationalism in school curricula, suggesting that teachers will need to know how to develop this new consciousness. His Holiness the Dalai Lama (cited in Kraft [60] p. 2) directs attention to the need for individual responsibility in this matter that:

The question of real, lasting world peace concerns human beings, so basic human feelings are also at its roots. Through inner peace, genuine world peace can be achieved. In this the importance of individual responsibility is quite clear; an atmosphere of peace must first be created within ourselves, then gradually expanded to include our families, our communities, and ultimately the whole planet.

In higher education, I have proposed, together with others (Lombardo [61]; Macdonald [62]; Maxwell [27]; Nylander [63]), that the conscious cultivation of wisdom is becoming a crucial component of the future work of universities. But history has shown that wisdom and its development is quite a complex and elusive topic.

Within the Western university system, most scholarship has been focused on defining, determining the parameters of, and working out how to teach worldly wisdom (see, for example, the range of approaches in Sternberg and Glück [25]). Such approaches have excluded, but not necessarily discounted, aspects of the manifestation of wisdom in a person that cannot in some way be measured or aspects that other people do not recognise as being "wise". Needing to define and measure wisdom has created several epistemological and methodological problems when the study of wisdom is being approached from the 
same industrial, colonial mindset that has caused the disappearance of the topic from the very institutions trying to study it.

First is a methodological matter that speaks to an a priori assumption that humans can recognise the wisdom in another person. This problem is evidenced by the common practice to ask research participants to identify other people who are wise when these participants have no developed understanding of wisdom. In my many discussions, it became clear that the ancient view of assessing wisdom is that assessment can only be undertaken by wise people. In this view, the scientific method of determining wisdom might be considered akin to asking a child in kindergarten to identify the characteristics of a skilful teacher. Addressing such critique, Sternberg proposes that people have a wisdom prototype "somehow stored in their heads" (Sternberg [48] p. 148). Ardelt [47] (p. 276) theorised that wisdom might be a latent variable with cognitive, reflective, and affective effect indicators. The sense of latency or prototype allows researchers to ask all humans about their assessment of wisdom, what it might be, and how it can be recognised, but such an approach is not without its limitations.

The current search for wisdom attributes has garnered lists of potential characteristics that might indicate that a person is "wise" and then implements programs to develop such characteristics. This approach is also commonly followed in leadership studies. In both cases, only those who exhibit socially determined characteristics of "leadership" or "wisdom" are then deemed to be so, thereby neatly if not somewhat circular in argument proving that such elusive human aspects are, indeed, socially constructed.

Second, and to make it more complicated, many Indigenous and traditionally-oriented societies continue to employ alternative epistemological structures that shape cultural differences in the way that wisdom is understood (see, for example, Grossmann and Kung [64]). The problem is that since these societies and peoples began being drawn into the globally interdependent economy during the recent period of industrialisation and colonial expansion from the 1800s, they have been increasingly required to adopt ways of thinking and employ the outsider language for the "quality" of their institution and the degrees conferred by them to be recognised in competitive global rankings. Therefore, one needs to be cautious of research about wisdom in "other cultures" because few places on the planet have not been taught to think and know within a particular epistemological mindset shaped by profit-driven motives and an internationally competitive ethos (Habermas [65]).

My cross-cultural, comparative research over many years reveals that people are no longer sure whether it is worth maintaining and preserving their storehouses of locally developed and acquired worldly wisdom because of the rapid pace of change around them. Under the impact of COVID-19, many are saying that their people are going back to the old ways, so there are many competing and conflicting pressures on humanity about what knowledge and whose ways of knowing will provide the best way forward. Young ecological activists such as Greta Thunberg have used the internet to encourage youth in myriad cultures to protest the unbalanced focus on profit accumulation at the expense of the planet's environmental health. Young peoples' views of the importance of developing wisdom skills to tackle such global challenges are of great importance now, and yet, we know little about how to teach for such practical wisdom and whether young people will trust the contemporary university to prepare them for the challenges ahead.

The third, and most pressing matter, is that the pursuit of the study of wisdom for problem-solving has steered research away from the concept of wisdom for selfdevelopment and questions about how such wisdom arises and why wisdom arises across human history. It would seem that from ancient times the idea of the development of the individual is a precondition for the development of good problem-solving skills, and yet modern institutions of teaching and learning seem disinterested in this aspect. Few modern scholars focus their research efforts on understanding how an individual human comes to apprehend something like wisdom and examining how it can be taught, seeking a solution to the question of whether it is possible to teach the development of wisdom (pedagogy), 
what might be its constituent parts (curriculum), and if yes, then how to develop wisdom in the current era.

Such questions continue to occupy my research, working in initial teacher education and preparing students attending university to become teachers and academics. Few would disagree that such future educators need to have wisdom and help their students develop along this pathway, but there is an apparent lack of interest in the university doing such work. Without concerted efforts to develop effective pedagogy and curriculum, the future of wisdom in universities seems lost under current constraints. Is it a simple matter of marketing? Or of the adage: Build it, and they will come? Clearly not. The concept of wisdom for self-development is being forgotten, while one of its outcomes, wise problem-solving, continues to be the focus of attention and growing demand. In a world of push-pull economics, it would seem that there needs to be the push of expectation created in the professional associations and workplaces of the future for the university to be producing graduates who have excellent self-awareness and problem-solving skills that come from purposive development and the pull of university marketing and global rankings that rate the development of such skills highly as a contributor to the quality and legitimacy of the postmodern university. In such a way, the concept of wisdom development and its pedagogies would be supported and driven to solve many issues that lay languishing in scholarship because of lack of interest and research funding.

In my professional career as an academic, I have taken up Toffler's [41] challenge quoted earlier (see also Toffler $[66,67]$ ). As someone who educates the next generation of teachers and provides professional development (Ma Rhea [68,69]), I ask my students what they want to learn at university. Their answers are always surprising and, at least for these pre-service teachers, in contrast to what universities think they want. Mostly they want guidance about how to survive and thrive in their chosen profession. They are adept at searching out and sorting volumes of information, dislike PowerPoint slide presentations, really appreciate collegial conversations and enjoy engaging with their classmates about how to look after themselves, employ effective pedagogies, deal with the overcrowded curriculum in differentiated classes, develop some personal skills, and survive the daily rough and tumble of the twenty-first-century classroom.

They like the ideas I offer them about needing to balance their intellectual, cognitive understanding of the world with developing their capacity for wisdom, grounded in practical exploration of topics such as wellbeing, ethics, emotional intelligence, mindfulness, and meditation. They take up the challenge and express surprise that they found the process both enjoyable and interesting. I am encouraged by their responses to continue to build such activities and explorations across the subjects that I teach. In the next section, I will briefly discuss the methodological approach I have used to develop my synthesis of time-honoured pedagogies to develop wisdom.

\section{Methodological Approach}

My research into wisdom, particularly the elements of pedagogy that might encourage its development in a student, has been grounded in inductive methods, relying on a descriptive, interpretative approach that has collected and examined the narratives of participants in teacher education programs about their views and understandings of wisdom and the impact of their respective national pedagogies and curricula. Shaped by the research approaches canvassed in the early years of my research into wisdom in education (Cohen and Manion [70]; Merriam [71]; Miles and Huberman [72]; Silverman [73]; Strauss and Corbin [74]), I have often employed case study research methodology across numerous small research studies (Merriam [71]; Stake [75,76]; Tellis [77]; Yin [78]). Narrative inquiry has been a feature of my overall approach following Connelly and Clandinin [3] (see also, Clandinin and Connelly [2]; Clandinin et al. [4]).

I have also employed methods derived from the field of cross-cultural comparative anthropology (for example, Mace et al. [79]) because of the need to think about wisdom as arising independently in disparate geolocations but potentially sharing similarities while 
being mindful of addressing "Galton's problem" (Naroll [80]) about non-independence in comparative studies. In my foundational research that examined the historical development of wisdom and its role in universities in Thailand and Australia, the ever-present methodological issues raised in considering two linguistic contexts have been amplified over many years. Hongladarom's [81] challenge remains as pressing as it was in the early 1990s:

\begin{abstract}
A translated statement, like other types of utterances, is polymorphic in nature. That is, we cannot claim it to be identical, in all respects, with the original utterance which it addresses. The translated product is never neutral, as it always incorporates at least one more voice, one more point of view.
\end{abstract}

(Hongladarom [81] p. 55)

Over the years, I have understood that I am researching the interactive space between cultures where I have focused on avoiding a priori ethnocentric assumptions between the words. My travels and research into wisdom expanded to encompass conversations in Yugoslavia (as it then was), France, Germany, Czechoslovakia (as it then was), Austria, England, Ireland, the Scandinavian countries, Portugal, Italy, Greece, Morocco, India, Japan, the Philippines, the United States, Malaysia, New Zealand, Vanuatu, and New Caledonia. In particular, in the early 1990s, a group of scholars from Fiji, Papua New Guinea, Japan, Vietnam, Australia came together at the WCCES conference in Sydney to raise the issue of the loss of wisdom in education in the Asia Pacific region, a group of scholars that have now influenced a generation of emerging research auspiced by the Oceania Comparative and International Education Society.

Closer to home, I undertook my teacher training in an Australian central desert community of Pitjantjatjara-speaking people, beginning my understanding of wisdom and its pedagogies that has been preserved in oral tradition. Over the years, this has extended to conversations about wisdom pedagogies with descendants of Adnyamathanha, Bardi, Boon Wurrung, Cammeraygal, Gija, Kaurna, Kuring-Gai, Luritja, Jaru, Ngarrindjeri, Ngunnawal, Pitjantjatjara, Yolngu, Yorta Yorta, Wurundjeri, and Wik, and I acknowledge their generosity in teaching me aspects of the language of their estates and waterways, flora and fauna, and matters of Country.

It has been necessary for me to work in the space of dialogical exchange (Bakhtin [82,83]) and communicative action (Habermas [84]) to tease out the intricacies of what wisdom might be, how it is expressed in language, what its aspects are and how it has been cultivated. For example, scholars (for example, Besley and Peters [85]) have raised issues related to ethnocentrism, cultural relativism, and universalism that have been central to my ongoing efforts to bring the vital particulars of different expressions of pedagogical considerations to hermeneutical challenges I have faced. Vološinov [86] helpfully discusses the errors of both abstract objectivism and individualistic subjectivism in the linguistic study of language and argues that "the utterance is a social phenomenon" (Vološinov [86], p. 82). He says, "Contexts do not stand side by side in a row, as if unaware of one another, but are in a state of constant tension, or incessant interaction and conflict" (Vološinov [86] p. 80). In my transcription of interviews and in notes that summarised other conversations, my approach was shaped by my understanding that data cannot simply be regarded as text without texture. Hongladarom's [81] (p. 53) describes the relationship of text to texture in this way:

I have used the word "texture" to contrast with "text". "Texture" refers to contextual meanings which include voices embedded in texts. A text without texture is monologic. The relationship between text and texture is crucial for our understanding of the usages of words...

I acknowledge her contribution in the formulation of how I pursued research in Thailand, collecting, examining, analysing, and understanding data because of the many hours we spent discussing the problem of conducting interviews across cultures. She says (Hongladarom [81], p. 53): 
This, as I see it, is a crucial problem of methodology that faces us when we try to elicit data from native informants and analyse them for the purposes of our studies. Often, we overlook the fact that linguistic data are involved with intentions, and our informants are social agents, not mere data-producing objects. It is legitimate that we want to focus on hard data and analyse them as if they were a text. But in creating text, we leave out the texture, which is an integral part of it. It is this texture that gives us a clue about what sort of interests that native speakers have in working with us and allow their voices to blend, interact, or argue with our researcher's voice. The text helps us to grasp the referential meaning of the utterance; its texture enables us to see human conflict that shapes discourse.

Ultimately, my abstraction of these vital elements allows a long history to develop about what I have found. In presenting these ideas to my participants in the dialogical exchange, our ideas are, together, revised. Beyond the ongoing process of checking for meaning and sensemaking (Mills et al. [87]), I have engaged with scholars in higher education studies in the global South in the argument for the need to decolonise universities (Ma Rhea [39,88]; Battiste et al., [89]; Dei [5]; Mbembe [90]; Thaman [91]).

In this paper, mindful of the matters discussed, I have undertaken a metasynthesis of extant literature, stories, and interpretations of ancient artefacts to shape my analysis, adapting the metasynthesis method developed by Finfgeld [92] and Finfgeld-Connett [93]. I found her overarching intention to understand sensitive and complex aspects of a topic useful for examining wisdom-developing pedagogies. Finfgeld's approach synthesises and interprets data across the existing literature and results in the reconceptualisation of ideas and practices. I have found that using an adaptation of her method to my context allowed me to grapple with comparative, historical, and diverse cultural contexts through metasynthesis.

Database searches were conducted using a range of relevant search terms to locate the literature for this review. The academic literature was obtained through philosophy, psychology, anthropology, religious studies, and educational databases such as Informit and ProQuest and WorldCat library searching. Grey literature traces found in the reference lists of blogs and non-academic self-improvement materials were obtained through web search engines such as Google and various literature preservation sites such as the Gutenberg Project. The searches were carried out at two levels. First, databases, library catalogues, web searching, and literature preservation websites were searched using various combinations of the following words and phrases: wisdom; self-improvement; human consciousness; ethics; wisdom; character development; pedagogy; education; religious studies; religion; spiritual; holistic; postmodern; critical thinking; teach; and, learn.

The results from these electronic searches were individually reviewed for possible inclusion in this study. In combination, this first-level search yielded an extensive list of publications and grey literature that were identified to be relevant to this study. The next level involved searching the databases for literature within each of the sub-themes identified. For example, the initial search identified various pedagogies used to develop axiological, ontological, and epistemological characteristics in the learner. Next, a second database search was conducted using various combinations of the original words and phrases that indicated support for comparable, scalable, and teachable aspects of wisdom development found in discrete ancient traditions. Reference lists drawn from recent articles, research reports, and book chapters were also scanned for relevant documents. This secondlevel search yielded a combination of scholarly and non-academic literature involving cross-cultural, comparative analysis of empirical studies. The sheer volume of ancient texts and contemporary commentaries and adaptations of those texts required many to be excluded because they did not indicate the pedagogical approach used to teach the development of wisdom. Only results that provided traces or explanations about the pedagogies of ancient traditions were included in the study.

The next stage in the analysis involved bringing all the included literature together with transcripts of over 800 interviews and notes from other conversations I have con- 
ducted over these last 30 years and examining them using Leximancer, a software tool that performs a computer-aided content analysis and, thus, goes beyond a simple keyword search (Poser, Guenther, and Orlitzky [94]; Smith and Humphreys [95]). Such software allows for the analysis of the semantic and contextual structure of selected data. Hence, I have been able to gain a view of the semantic context of words such as "wisdom", "teach", and "learn" within these various data sources. Conceptually related concepts were grouped by a theme. As Smith and Leximancer [96] note:

Leximancer is a text analytics tool that can be used to analyse the content of collections of
textual documents and to display the extracted information visually. The information is
displayed by means of a conceptual map that provides a bird's eye view of the material,
representing the main concepts contained within the text as well as information about
how they are related..

In summary, I am sympathetic to the inherent problems of the "grand narrative" and also know that without the capacity for big picture abstraction that we can become lost in the particularity of a story, at the expense of the broader patterns that might support a deeper understanding of a problem or trend. Drawing on methods of data collection and analysis from anthropology, philosophy, psychology, sociology, and education, using historical-comparative, cross-cultural research methods, I have undertaken a metasynthesis of extant pieces of literature, using the tools of Leximancer to enable the small stories to be incorporated in such a manner as to allow a Janussian perspective on pedagogies for developing wisdom in higher education.

\section{A Note on Teaching Modalities over Time}

A notable feature of my synthesis of the pedagogies of age-old wisdom traditions is that methods of transmission of the idea of wisdom have changed over time, reflecting that certain aspects of problem-solving and understanding about self-development are particular to certain geolocations, cultures, or economic arrangements or divisions of labour or historical periods even as the core concerns remain markedly similar. My analysis shows, somewhat surprisingly, that for most of these 12,500 years, the idea of wisdom and pedagogical approaches to the development of wisdom has remained relatively stable despite its meaning being quite challenging to express. This challenge may reflect the process of "evolutionary hermeneutics", so helpfully argued by Csikszentmihalyi and Rathunde [97] (p. 25). My findings support their proposition (Csikszentmihalyi and Rathunde [97]) that there is a "meme of wisdom" [that] contains a nucleus of meaning that has transmitted relatively unchanged for at least 80 generations, providing direction or human thought and behaviour" (p. 26). As noted, Sternberg proposes this "meme" as a "prototype" of wisdom (Sternberg [48], p. 148). I think this latency, meme, or prototype of wisdom has probably existed within the human psyche for over 3000 generations.

My findings suggest an essential insight into what might have impacted the progress of the evolutionary hermeneutic, the methods of human transmission of their understanding of the wisdom meme. Over millennia, pedagogies employed for self-development and practical problem-solving have been shaped by the methods of communication that were available to teachers. In the long history of humans teaching each other about wisdom, the most enduring is the oral modality. From the time of the development of homo sapiens in geolocations as diverse as Xihoudu and Xiānréndòng, China, Nile Valley, Africa Australia, Papua New Guinea, Indonesia, Tasmania, Southern Asia, Hokkaido, Japan Alaska, and Meso-America, Indigenous Peoples developed mental forms of communication, then language and sign language. There is also evidence that communication was performed using symbols. The most enduring, the oral form of transmission of information, is the oldest pedagogical modality and continues to be a dominant form of teaching in face-to-face formal and informal contexts.

As the peoples of these ancient cradles of civilisation emerged from the last Ice Age, there is evidence of the accelerated development of spoken language. Artefacts and cave 
drawings can be found in places such as Nánzhuāngtóu, China, Maya, Mesoamerica, Jericho, West Bank, El-Badari, Egypt, Yang Shao, China, Çatalhöyük, Turkey, Ain Ghazal, Jordan, Jiahu and Pengtoushan, China, Mesopotamia, West Asia, Norte Chico, Peru, Sumeria, Iraq, Mohenjo-Daro and Harappa, Indus Valley that trace the development of language, pictographs, cuneiform, and hieroglyphics, and also the early development of mathematics. Written forms were slowly augmenting oral transmission of knowledge. Linguistic, historical, and archaeological studies and stories of modern descendants of these early peoples confirm that some families, clans, and tribes continued to use oral forms of teaching.

At the same time, some began to develop written forms of knowledge about their emerging societies that needed to be recorded, such as governance decisions, trade, and commerce. About 5300 years ago, some societies, such as the Minoan, Egyptian, Sumerian, Norte Chico, and Mayan, began collecting and recording cultural information. It became necessary to teach people how to read and write. Development of early centres of teaching and learning occurred during this time, predominantly as scribal schools such as found in Egypt and Mesopotamia from about 2061 BCE. An analysis of these ancient records suggests that information about self-development and wisdom continued to be transmitted face-to-face using oral methods. Even as some of the ancient nomadic peoples and pastoralists became more sedentary over time, the various wisdom traditions seem to have relied on oral transmission for individual development practices while starting to record aspects of spiritual and religious traditions such as rules and guidance for living as the modality of writing became more accessible, and more people had learned to read and write. From about 3700 years ago, mastery approximation was guided orally by a more senior knowledge holder, through direct teaching and experiential learning practices, as can be found recorded in the early texts of Hinduism, Judaism, Zoroastrianism, Buddhism, Jainism, Shinto, Christianity, Taoism, and Islam. By 685 BCE, for example, there are records of a library in Nineveh. Each of these traditions developed methods to begin to record the teachings. Confucian ideas were written in the Lishu or Clerky script about 500 BCE, with a foundational text of Hinduism, the Rig Veda, beginning being preserved in written form by 300 BCE. The Mayan codices were also written around this time but were destroyed during the more recent period of industrial colonialism. Slowly, other traditions began recording teachings and often the pedagogical approach to teaching, first on all manner of materials. As the production of paper became more technologically advanced, many of these early versions of teachings started to be transposed onto paper and made into books.

The development of the book made of paper that incorporated aspects of oral teachings made a significant impact on the methods by which teachers undertook the transmission of information about the development of wisdom. Students could be given access to sections of teachings to study and discuss. In addition to group learning and memorisation that were popular methods in the oral traditions, manual text reproduction became part of the process of learning through oral repetition and written copying of core teaching texts. The sheer volume of copies of these texts has allowed archaeologists and linguists to have a rich trove of material to translate, compare and elaborate on the wisdom traditions and their respective pedagogies.

The practice of using oral and written transmission of information became relatively stable from about 2200 years ago until about 400 years ago. The development of the printing press allowed for exponential dissemination of information through printed books, journals, monographs, and other written materials. This advance in how humans could preserve and maintain information had, once more, been a significant influence on how teaching could be undertaken. The development of printing was one of many technological advances that enabled the colonial industrial period to occur. The form of schooling that is more familiar in the contemporary era emerged from this period. Schools for teaching reading, writing, and arithmetic were foundational to establishing colonies by the Portuguese, Spanish, Dutch, English, French, Germans, and Swedes. The children of colonists were required to be educated as if they were in their home country. The dissemination of printed schoolbooks was a vital element of the transfer and gradual 
imposition of colonial and industrial ideas globally. The wisdom "meme" was yet again reframed by an emerging mode of thinking known as the scientific method. Teaching and learning revolved around the use of textbooks that contained information that had little to do with students' experiences, written as they were by curriculum writers in far-flung colonial centres. Local evolutionary hermeneutics about the development of wisdom and its pedagogies were severely disrupted and sometimes destroyed by new ideas and new masters.

Notably, many Indigenous and local communities have continued to teach their wisdom traditions orally across thousands of generations. Others have preserved their wisdom traditions through the written form, and the preservation of these traditions was greatly enhanced through printing technologies. In the modern era, three distinct modalities come together to shape pedagogies used by teachers to develop wisdom in their students, and I would argue that we are on the cusp of a fourth, the virtual, where advances in technology are allowing teaching and learning to occur entirely online. In terms of evolution, only those written and printed texts that have easily converted to digital forms via the internet may survive. Interestingly, it appears that the oral modality is experiencing a re-emergence through an extraordinary array of lectures on self-improvement, together with apps for mindfulness, meditation, and chanting, taking the idea of wisdom, its meme, and its pedagogies into a new phase of evolutionary development.

\section{Information, Knowledge, and Wisdom}

In modern scholarship, it has become expected that one defines one's key terms. As noted, in examining a concept such as "wisdom", this can lead to constraining and defeating circularity because only that which can be defined is then studied. My methodological approach requires consideration of the array of stories, artefacts, texts, and blogs that have attempted to capture its meaning for that time and place. An extensive metaanalysis of empirically focused literature about wisdom undertaken by Trowbridge [98] demonstrates that a primary research priority by wisdom scholars has been to establish parameters around the idea of wisdom such that it can be studied. His meta-analysis also demonstrates a more general problem, as introduced in the previous section, that working across different cultures, academic domains, and systems of religious, spiritual, ideological, psychological, and philosophical thought requires an appreciation of alternative domain ontologies (Bawany and Nouman [99]; Stancin et al. [100]), with their distinctive epistemologies and axiologies. Equally so, to study the manifestations of wisdom in a person and try to reproduce those characteristics (Sternberg [24]) is sharply distinct from approaches that seek originary causes for the arising of wisdom in a person and the codification of a pedagogical pathway to create the causes and conditions for the emergence of such wisdom (Ma Rhea [39], Diamond [101]).

Instead of studying people who are considered wise, an undertaking that is becoming more established in Wisdom Studies in universities, I argue here that more focus needs to be put on understanding wisdom-developing causes and conditions and then adopting pedagogies that facilitate their development in a student within the discipline of Education (see also, Sternberg and Hagen [102]) and across university disciplines (Maxwell [55]). In the following sections, I will offer a discussion of the key terms for this paper, namely information and knowledge, wisdom, and higher education, before returning to an examination of some of the pedagogical considerations needed for universities to develop wisdom in their students.

\subsection{Information and Knowledge}

The English language word "information" (OED [103]) is defined as: the shaping of the mind or character; communication of instructive knowledge; education, training.

It suggests an element of purpose by communicating information, and teachers commonly bundle pieces of information together as curriculum content with pedagogical intent. 
The English language word "knowledge" (OED [104]) is defined as: the fact of knowing or being acquainted with a thing, person, etc.; acquaintance; familiarity gained by experience.

This definition suggests that information is taken into the learner's mind and, through various internal processes and activities, becomes tacitly held knowledge. It can mean that a person uses the information to try something, thereby gaining knowledge from experience. It also is used to suggest an intellectual perception of fact or truth. In academia, it can mean that one has information acquired by study or by research, and it describes the range of one's information, learning, or erudition. It suggests a familiarity or conversance, as with a particular subject or branch of learning. Outside individual cognisance, knowledge is also something that a culture or a society can have. In this sense, it is the storehouse of truths or facts accumulated by a society, group, or culture over time.

Knowledge is also held on a continuum that ranges from facts to partial knowledge through to complete knowledge. For example, a child might be given information that a fire burns. One might gain partial knowledge of this fact by having an experience of being burned. Therefore, the information is consolidated by an experiential understanding of the fact. This consolidation allows for partial knowledge, and it is the extent of most knowledge acquisition. The journey to full knowledge begins by asking critical questions through information seeking: is it always true that fire burns? Researching the topic, an adult might discover that sometimes it is possible not to be burned by fire. They might find out that by practising techniques to control one's mind and breathing, such as preparations for fire walking, they might walk on hot coals and not get burned. Being given the information to enable learning such techniques and having the experience of walking on fire and not getting burnt enables a more complete knowledge of the subject.

Philosophy as a discipline has done much to preserve the pathway towards complete knowledge through questioning and logic that have enabled the human concepts of information and knowledge to become complex and more expansive to reflect the sheer diversity of human experience. Scheler [35] develops the concept of knowledge to propose that knowledge is produced from three distinct ways of knowing - religion, metaphysics, and positivist science- that are the outcome of various social forces. His concept of "way of knowing" is helpful because it describes a framework for a person to receive new information and scaffold it into an already developed understanding of the world.

Wisdom finds its scholars in these three domains, and each has its guidance for developing its version of wisdom. Scheler's [35] scholarship also reflects the influence of ancient ways of describing the concept of the sorts of knowledge that can lead to the development of wisdom that arose from the early oral teachings of Indigenous senior knowledge holders where this way of knowing finds its most robust surviving presence in more traditionally oriented societies such as India, Thailand, and some Indigenous cultures (Maina [105]). In sharp contrast, and arising from a more recent time, Scheler sees positive science as having the following traits. It rests on differentiating the arbitrary from the particular. The action is done " ... by observation, experiment, induction, deduction" (Scheler [35] p. 165). Science aims to control the natural world after determining the mathematical relationships of all things, and it is the scientist who is the leading type. The historical movement of the scientific way of knowing hinges on a:

\section{... rational, specialised science based on a division of labour which serves a differentiated social body and a trained body of department officials and seeks to produce a world concept that makes technical control of the world possible.}

(Scheler [35], p. 168)

Within this explanation, it is possible to begin to theorise why the scientific approach to information and knowledge about wisdom have been possible to preserve in the university while other ways of knowing have been more challenging to include. Stepping outside the English-language definition, other languages can express similar ideas and with the same array of possible meanings and interpretations. "Knowledge", for example, appears to be both something that can be tacitly understood while at the same time also existing before the individual as an a priori element of each society's storehouses of knowledge. 


\subsection{Wisdom}

The English language word "wisdom" (OED [106]) is defined as: the capacity of judging rightly in matters relating to life and conduct; soundness of judgement in the choice of means and ends; sometimes, less strictly, sound sense, esp. in practical affairs: opposed to folly.

I have yet to enquire of a particular speaker of a language about wisdom and be told there is no such concept. My metasynthesis and analysis of stories and ancient texts show that the idea of wisdom is as old as humanity and its ontologies and pedagogies continue to be held by Indigenous peoples and other societies oriented towards their traditional ways of knowing (Battiste [107]). In my discussions of this word in its English language form across linguistic differences, people will sometimes struggle to convey its nuances, as people always have found when trying to commit these ideas in oral and written forms, whatever the language. تجاوز الحكمة, ninti, la sagesse, 超越智慧, বিজ্ঞতা, yalomatua, Weisheit, ภูมิปัญญาวิชชา, мудрость, 智識, kebijaksanaan melampaui, Visdom, Hekima, and sabiduría provide examples of ways humans have found to approximate the expression of some aspect of wisdom or another as they talk about how their culture understands and teaches this concept.

The study and practices associated with developing wisdom fell out of favour in universities during rapid global exploration and industrialisation by people in Europe when universities were forming their modern character. Scholarship about wisdom has recently emerged as a worthwhile research topic, but its study and practices have not. The Wisdom Page contains an excellent collection of reports of academic research concerning wisdom (http: / / www.wisdompage.com/wisresearch00.html, accessed on 26 July 2021). In Western psychology, for example, and a closer examination of the meaning of wisdom is now proceeding. Sternberg [24] shaped the field with his foundational book that begins to research this elusive topic. He believes that it is time for the psychological sciences to begin afresh to develop an "understanding of wisdom and to point the way for future theory and research" (Sternberg [24], p. ix). He defines a balance theory of wisdom as:

... the use of one's intelligence, creativity, common sense, and knowledge and as mediated by positive ethical values toward the achievement of a common good through a balance among (a) intrapersonal, (b) interpersonal, and (c) extrapersonal interests, over the (a) short and (b) long terms to achieve a balance among (a) adaptation to existing environments, (b) shaping of existing environments, and (c) selection of new environments.

(Sternberg [24,108,109])

Kitchener and Brenner [110] see knowledge as being but one aspect of wisdom. They suggest four aspects of reflective judgement that are pertinent to their discussion about wisdom and its understanding (Kitchener and Brenner [110], p. 213):

- the presence of unavoidably difficult, "thorny" problems inherent in the lives of adults;

- a comprehensive grasp of knowledge characterised by both breadth and depth;

- a recognition that knowledge is uncertain and that it is not possible for truth to be absolutely knowable at any given time;

- a willingness and exceptional ability to formulate sound, executable judgments in the face of uncertainty.

One, therefore, needs information and knowledge to be wise, but simply internalising knowledge is not enough to be wise. This approach to wisdom distinguishes that the more common definitions avoid accumulating information on the one hand and being wise on the other and begs what wisdom is.

Aristotle posited that there were two sorts of wisdom that he labelled practical and metaphysical wisdom reflecting the already understood differences between two manifestations of the concept: one manifestation has been studied its more worldly, practical expression, trying to develop methods for students to learn what has been termed practical wisdom within churches, universities, and schools. The other manifestation of wisdom 
that has been pursued historically has been the development of wisdom, teaching, and learning the knowledge also identified by Scheler as the metaphysical, sometimes called the secret, sacred, occult, transcendental path. This path of higher learning shaped the pedagogies established in the original schools, universities, and spiritual traditions (Conze [111]; Takahashi [112]).

If, as I propose, the concept of metaphysical, transcendent wisdom is being forgotten (Diamond [40]), it is unsurprising that academic research in Wisdom Studies has focused more firmly on the worldly, practical, and activist aspects of wisdom. The "Enlightenment", east and west, reflects the human shift in worldview from the search for Enlightenment beyond the bounds of the material, mundane world towards a more pragmatic engagement with the here and now. In European scholarship, there has been sustained scholarly effort to turn away from the metaphysical path to pursue enlightened modernity and postmodernity (Habermas $[65,113])$. Such an approach, perceived by other nations to have given the West its economic and military competitive edge, saw national universities and ancient institutions of higher learning across the world turn away from their wisdom traditions in search of worldly success.

Wisdom teacher, Copthorne Macdonald, heralded this shift, arguing for the need to develop a third sort of wisdom that he named "activist change-the-world wisdom" (http:/ / www.wisdompage.com/wisdomvarieties.html, accessed on 26 July 2021) that would appear to be strongly associated with the practical-wisdom development approach. Universities and seekers of wisdom in the contemporary era seem to have some sense of how to approach those aspects. As noted, sustained research has attempted to develop lists of characteristics held by a person who is considered wise. An excellent exemplar developed by Copthorne Macdonald shows the variety, and commonality, of responses (see Figure 1).

\section{The Wisdom Page}

Forty-eight positive human characteristics that have been associated with wisdom

\begin{tabular}{|l|l}
\hline compassion & gratitude \\
responsibility & deep understanding \\
positive attitude & hopefulness \\
integrity & wonder \\
acceptance & humility \\
self-knowledge & dedication \\
detached concern & insight \\
adopting multiple perspectives & joy \\
empathy & kindness \\
aliveness & nurturance \\
appreciating ramifications & self-investigation \\
caring & openness \\
attentiveness & patience \\
commitment & self-actualization \\
desiring the good of the whole & peacefulness \\
cooperation & reflectiveness \\
intuitive understanding & respect \\
curiosity & self-sufficiency \\
willingness to risk & serenity \\
equanimity & sound judgment \\
fairness & truthfulness \\
generosity & vision \\
self-acceptance & appreciating significance \\
discernment & breadth of considerations \\
\hline &
\end{tabular}

Figure 1. Forty-eight positive human characteristics associated with wisdom (http:/ / www.wisdompage. com/WisdomCharacteristics.html, accessed on 26 July 2021) [Reproduced with permission]. 
The enduring issue about such otherwise helpful lists is to determine which of such characteristics can be taught and by what methods so that a student learns practical wisdom. There does not seem to be any cultural memory within the global, standardised education system of a reliable pedagogy or curriculum that could claim to know how to develop wisdom in a student that does not need to reach back into ancient concepts and practices that are, by now, long forgotten and more likely to focus on metaphysical matters. More critically, the disinterest in the practical, problem-solving aspect of wisdom and its development currently shown by university administrators, government funders, and students-as-consumers reflects a broader societal malaise that no longer considers the pursuit of wisdom as being of any relevance to their lives. The difficulties faced by wisdom scholars reflect these two inter-related aspects; first that we do not know how to teach the development of practical, problem-solving wisdom that is not reliant on the pedagogies of its metaphysical antecedents, and, second, there is no appetite for its development at the university level. It is, therefore, necessary to ask: what has happened to the idea of education for wisdom in the human story?

The idea of balance in Sternberg's definition is confirmed in my research (Diamond [101], 2021; Ma Rhea $[69,114,115])$. Balance seems to be a common aspect in research findings about wisdom to some degree. Differences may be attributed to the cultural frameworks used in a country such as Thailand, where Buddhist philosophy suggests three ways of knowing, morality, concentration, and insight understanding. Scheler [35,116] also concludes that wisdom is about finding the balance between three different knowledge domains that enable the emergence of wisdom, as does Ardelt $[46,47,117]$ in her work.

\section{Balance Pedagogies for the Modern Education for Wisdom}

In trying to elaborate on how wisdom might be cultivated, it is necessary to consider balancing the domains of wisdom development and the implications for pedagogy. Drawing on my study of many ancient texts, I have identified what I consider to be a reasonably consistent approach across them (see also Battiste [107]; Beck [118]; Carpenter [119]; Cheng [120]; Cheng and Xu [121]; Edwards [122]; Ellis [123]; Graham [124]; Jianwei [125]; Sabki and Hardaker [126]; Simms [127]; Smith [128]; Sternberg and Jordan [49]; Wei [129]; Young [130]; Zongjie and Chunyan [131]). The rationale for this approach is that the cultivation of wisdom requires information about, practice in, understanding of, and ultimately the balancing of three domains of knowledge: axiological, epistemology, and ontology.

Axiological development is focused mainly on how the value of something might be understood and judged. It can be conceived pedagogically through practices that develop morality and ethics, emotions, and the intuitive (Bauman [132]; Dewey [133,134]; Kane [45]); epistemological development through practices of critical thinking, reason, and logic, cognition, and deepening of insight understanding (Plato [135]; William of Ockham [136]; Descartes [137]); and, ontological development through practices of awareness and concentration, stillness, and access to the subconscious (Aristotle [138]; Lorhard et al. [139]; Wolff [140]; Decock et al. [141]; Zinn [142]). The figure "Balancing the domains of Knowledge" (Figure 2) gives a sense of the balance needed between these three domains.

\subsection{Pedagogies for Axiological Development}

It is possible to access oral stories and ancient written texts containing information about developing morals and ethics in the axiological domain. Some of this has been preserved in printed books but more artefactually. Some aspects are still pursued as character building as part of citizenship education in schools (Althof and Berkowitz [143]; Cooke and Carr [144]; Csikszentmihalyi and Nakamura [145]; Giroux and Purpel [146]; Kristjánsson [147]), but there is little of this development continued into the university level of education. In stories and writings, some now reproduced virtually in digital formmany sorts of observances were given to students to help them become aware of their moral or ethical decision-making and mature their emotional responses to various dilemmas and challenges. 


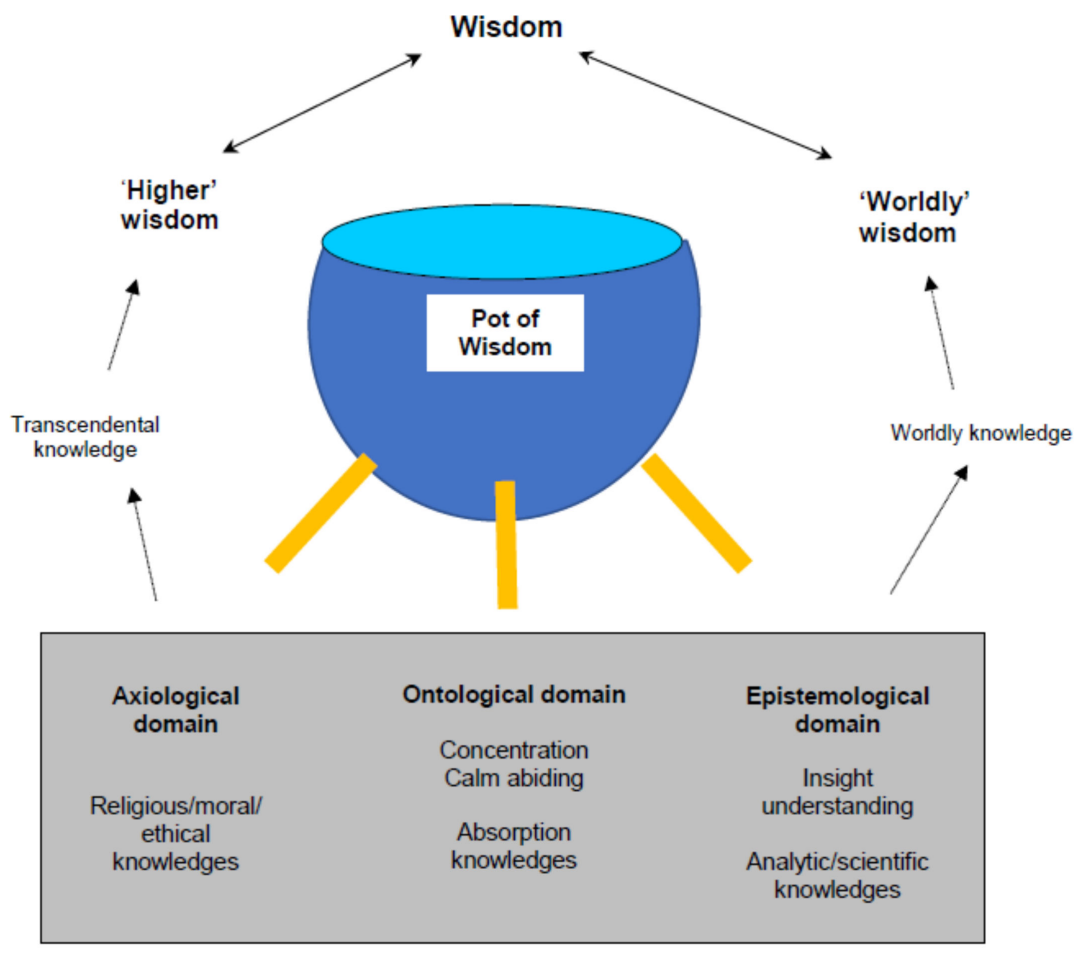

Figure 2. Balancing the domains of knowledge for the emergence of wisdom.

I found in my metasynthesis that in many traditionally-oriented societies, the axiological aspect is approached pedagogically as the first aspect to teach in the development of wisdom, and the teaching and learning that occurs provides the foundation for the development of the ontological and epistemological domains through practice and understanding. Universities, globally, have almost completely abandoned attempts to develop this aspect in their students except through extracurricular activities. The exception to this is the universities that have established themselves privately as religiously or philosophically focussed universities such as the Catholic, Islamic, and Buddhist university systems, the Kabbalah Centre International, University of Al-Qarawiyyin, Morocco, the Chinese Culture University, and universities such as the University of Creation Spirituality, Soka Gakkai International, and Ubiquity University. Using the balanced pot analogy, the development of knowledge in the axiological domain cannot, by itself, lead to the emergence of wisdom.

\subsection{Pedagogies for Epistemological Development}

In ancient systems of education for wisdom, the development of the epistemological domain came after laying the foundations of axiological awareness and ontological development first through teaching students about ethics, morality and values, and through practices of reflection, meditation, and concentration practice that allowed students a deeper contemplation of such information so that questions could then arise that would allow the development of the cognitive understanding of the issue, problem, moral or ethical value being considered.

In the evolving formal education system, during the period of global colonisation and industrialisation, axiological and ontological development became presumed to have been undertaken by the family, through religion, or in primary and secondary schooling, and ongoing development was substantially abandoned in favour of a focus on the development of critical thinking and societal development through the lens of science. The practices associated with critical thinking are similar to those of the ancients, transmitted first orally from teacher to student and later preserved by writing and later in books as practices to deepen understanding of the knowledge held by the student. The difference is that critical thinking has become the predominant domain of knowing without attention being given 
to the other two domains (Sternberg and Hagen [102]). In this way, using the balanced pot analogy, the singular pedagogical focus on the development of epistemological, cognitive forms of knowledge leads to the generation of more information but, by itself, cannot lead to the emergence of wisdom (Malaska [148]).

\subsection{Pedagogies for Ontological Development}

Interestingly, my metasynthesis has shown that in the ontological domain, practices associated with developing meditative awareness and concentration were maintained through the education modalities of oral stories and in writings in some societies and started to be lost in others. As the influence of printed information being produced by printing presses began to be felt through the expansion of the industrial, scientific, colonial model of education, new universities established in old societies such as found in India, Africa, China, and Mesoamerica rushed to establish themselves with the same epistemological emphasis as was happening in Britain, Europe, and America.

My analysis has found that the significant influence of the modern university approach is to have lost the capacity to prioritise the development of the ontological domain in any society. As many have observed, coffee culture drives restless humanity, and the incapacity of humans for peaceful contemplation brings me back to the words of His Holiness the Dalai Lama that without being able to feel peace through developing the experience of peace within oneself, there will never be global peace. Yet, our highest form of education, the university, seems at best disinterested in developing such capacity in students.

I think that the capacity of universities to help refuse planetary destruction lies in the skills they can embed in their core business that arise from such forms of concentration as meditation. The word "meditation" is often misunderstood as being passive. Most people seem content to seek an axiological moral or ethical framework through religion rather than pursue deep concentration skills and discipline. In universities, the relationship between the ontological and the epistemological has been the subject of lengthy debate. Many teachers of mind-stilling techniques have made their teachings accessible in virtual forms on the internet, on mobile phone apps (for example, Smiling Mind and Insight Timer apps), and in printed forms (see, for example, Ayya Khema [149,150]; Buddhadasa [151-154]; Buddhaghosa [155]; Nyanatiloka [156,157]; Macbeth [158]). All techniques have a shared learning outcome: the stillness of the mind. Simple awareness practices are methods to occupy the mind (both brain and heart in most traditions) so that brief moments of stillness can be experienced. Such practices establish a pedagogical gateway to the ontological.

\subsection{Balance Pedagogies for Developing Wisdom}

From my analysis, it becomes clear that for universities to develop wisdom, they will need to add to their already strong capacities in epistemological, cognitive development to integrate axiological and ontological development to such a degree that these domains can become as equally well-developed as cognitive development as the core business of the university. As the world moves into a mode of education still forming, the virtual, globally-reaching technological capacities create a new world of teaching and learning. Universities have to provide extensive online learning opportunities, and students can access almost overwhelming quantities of information about any subject. Universities are learning to help students curate individualised learning experiences. Many students seek courses that allow them to combine subject specialisations with well-being courses and opportunities for mindfulness classes and online meditation courses and mixing subjects in the social and physical sciences. It is unclear how this approach to university learning will solidify over time, but this new epoch of the virtual has re-established the ancient art of the oral through greater use and acceptance of podcasts and other forms of virtual, verbal presentation of assessment tasks. The move away from the written and reliance on printed books towards performance, oratory, and the amassing of human knowledge in virtual repositories such as Wikipedia and Google is fundamentally changing education. The consequence for the cultivation of wisdom is as yet unclear. However, it does appear 
that there is a return to the most fundamental method of that most enduring of human ways of teaching and learning, the oral, and this may yet become a way to rebalance the work of university education to again embrace pedagogies for axiological, ontological and epistemological self-development and problem-solving wisdom in students.

\section{Conclusions: Old Ways for Developing Wisdom}

Each modality, Oral, Written, and Printed, used by teachers for education, provides worldly and more esoteric examples of how education has enabled people to feed themselves and, equally, to consider their place in the cosmos. Ancient oral approaches have been used to develop wisdom and prepare people for the practical world of feeding oneself or employment, with teachers and academics supporting their students to make informed choices about their place in the world, the universe, and everything in between. As humans enter into a new global consciousness shaped by the virtual, using digitally, socially-connected networks and trying to understand globally shared problems, new teaching and learning approaches are also emerging to help societies adjust and evolve (Ferrari and Kim [159]).

In my research and through my leading professional development activities for teachers and academics, I have found that highly educated professionals are often at a loss to know what might be best for themselves in personal self-improvement. Also, they are left casting about for reliable information on what pedagogies they might use to support and enable their students' personal development of wisdom. Having them reflect on what, if any, approaches have worked for them in the past, it is possible to begin the journey to explore what old ways might be worth developing as an aspect of their professional toolkit supporting their students. Some have spoken of effective oral methods used in their church, temple, or mosque. Some have spoken of traditions preserved in written and printed forms of sacred texts. Some have had no exposure to anything religious or spiritual in their lives, and they speak of exploring the virtual, learning from blogs on websites and taking online weekend courses on mindfulness or meditation to help with their stress. Many participants report piecing together a personal philosophy that draws on an array of ancient and modern approaches that work for them. Gamification techniques in social media development are now influencing how people learn wisdom, wellbeing, self-care, meditation, and prayer. New apps such as Fabulous, Lojong, and Insight Timer connect like-minded people in circles of learning, encouragement, personal goal setting, and sometimes even in competition. Who can meditate for the longest? These are uncharted waters where the technologies of the virtual, advances in neurological sciences, and ancient wisdom traditions are meeting in podcast oratory, habit-forming disciplines, and Tik Tok performances.

Some scholars such as Hattam [50] have argued for a need to return to spiritual pathways like Buddhism in new forms such as socially engaged Buddhism, somewhat akin to Copthorne's wisdom activists. I see evidence of the ascendency of the oral once more, and as scholars of wisdom and its development, we need to understand more of the skills and practices of oratory as we continue to share our ideas in the virtual space of the open-access online journal, such as with this article. Indeed, I can foresee when we might craft a paper and provide a podcast of our main points or a spoken, performed version of the whole paper!

In conclusion, after much consideration, I suggest that a pedagogy for wisdom development shaped around the balanced pot analogy (Figure 2) could be beneficial. My analysis suggests that the axiological and ontological domains of knowledge are weak in the present university, also emphasised by Harvey [160] and Giddens [161]. Each observed that the sense of time is speeding up, that humans now have to work more rather than less even with our technological mastery, and although we have made significant material progress that as humans, we still feel dissatisfied. Every time I suggested to informants that it might be good to slow things down in the global education services market and think about what we are doing at universities, there has always been a strong objection, followed 
by a cascade of reasons why such an idea is impractical and impossible. Ironically, with the halt of international student migration as a direct impact of COVID-19, such a stop has been enforced. The question remains whether university leaders and administrators are willing and capable of seizing such a rare opportunity to reconsider the role they perform in society. I hope that the enforced quietness and slower pace in the aftermath of COVID-19 might allow universities to consider introducing aspects such as developing a program of wisdom development (Kegan [162]). This pause to consider could, by itself, encourage a path towards wisdom inquiry so well justified by Maxwell.

Indigenous Peoples have continued to rely on oral traditions to teach and learn, and the teaching and learning approaches that they have employed are, as yet, barely understood by people educated only in the world of the literate, of written and printed matter. The virtual modality offers new opportunities to return to the art of oratory still practised by Indigenous communities across the world (Biermann and Townsend-Cross [163]). The world of quiet, stillness, and an appreciation of space still forms part of these teachings, with the first lesson given to many outsiders being told that they talk too much. As Cataldi [164] so beautifully writes:

... if you stay too long in the third world
you will become
accustomed to silence and observation
leading to understanding
to abundance and malnutrition
immutably hand in hand
when that eager and rational voice
whose creature you are
whose instrument you had volunteered to become
grates like a radio on a bad day
you switch it off

In the last 30 years, some universities have begun to bring practices of meditation and quiet reflection into all the courses they each, drawing on their ancient cultural storehouses of knowledge to do so (Sivaraksa [165]; Diamond [40]). In Australian universities, there is little recognition that it might be critical to cultivating more than one way of knowing about this world and even less interest in developing axiological and ontological domains of knowledge. Even if we want to, for most of us, we do not know how to switch the mind off. In such a time of transformation into the pedagogies of the oral and virtual, education for developing dynamic wisdom will emerge if all the pot's legs are equally bearing the weight. The skill is to cultivate them all equally and then to determine the balance.

Funding: I would like to acknowledge the financial support for this project over 27 years starting with an Australian Government Research in Asia Award 1994-1996 that supported me to undertake my PhD in Thailand, the Smuts Visiting Fellowship in Commonwealth Studies (1997-1998), the Phayon-Thonghau Eiamlapa Award (2017-2021) and the Faculty of Education, Monash University.

Institutional Review Board Statement: This project was granted Flinders University Ethics Approval in 1993 under the title Universities and Wise Futures and by Monash University Ethics Approval [CF11/0559-2011000237] under the title: Buddhist mainstream schooling in Australia: A case study of the development of a Buddhist school in Victoria.

Informed Consent Statement: All participants in this project have given their formal consent to participate in various aspects of this research both orally and in writing where required.

Data Availability Statement: No data was used that is not referenced in this paper.

Conflicts of Interest: The author declares no conflict of interest. 


\section{References}

1. Lyotard, J.F. La Condition Postmoderne: Rapport sur le Savoir, Paris: Minuit, 1979 (The Postmodern Condition: A Report on Knowledge, Translated Geoff Bennington and Brian Massumi); Minnesota University Press: Minneapolis, MN, USA, 1984.

2. Clandinin, D.J.; Connelly, F.M. Narrative Inquiry: Experience and Story in Qualitative Research; Jossey-Bass: San Francisco, CA, USA, 2000.

3. Connelly, F.M.; Clandinin, D.J. Stories of experience and narrative inquiry. Educ. Res. 1990, 19, 2-14. [CrossRef]

4. Clandinin, D.J.; Pushor, D.; Murray Orr, A. Navigating Sites for Narrative Inquiry. J. Teach. Educ. 2007, 58, 21-35. [CrossRef]

5. Dei, G. Decolonizing the university: The challenges and possibilities of inclusive education. Soc. Stud. Études Soc. 2016, 11, 23. [CrossRef]

6. Nabobo, U. Exploring Yalomatua: Fijian Education and the Missing Link. Dir. J. Educ. Stud. 1994, 16, 41-54.

7. Teasdale, G.R.; Little, A. Open file: Culture and Education. Prospect. UNESCO Q. Rev. Comp. Educ. 1995, 24, 585-782. [CrossRef]

8. Kopong, E. Informal learning: A case study of local curriculum development in Indonesia. Prospect. UNESCO Q. Rev. Comp. Educ. 1995, 24, 639-652. [CrossRef]

9. Ma Rhea, Z. Changing Manifestations of Wisdom and Knowledge in Thailand. Prospect. UNESCO Q. Rev. Comp. Educ. 1995, 24, 669-682. [CrossRef]

10. Mel, M. Mbu: A Culturally Meaningful Framework for Education in Papua New Guinea. Prospect. UNESCO Q. Rev. Comp. Educ. 1995, 24, 683-694. [CrossRef]

11. Nabobo, U.; Teasdale, J. Education for cultural identity. Prospect. UNESCO Q. Rev. Comp. Educ. 1995, 24, 695-706. [CrossRef]

12. Thaman, K.H. Concepts of Learning, Knowledge, and Wisdom in Tonga and their Relevance to Modern Education. Prospect. UNESCO Q. Rev. Comp. Educ. 1995, 24, 723-734. [CrossRef]

13. Teasdale, G.R.; Ma Rhea, Z. (Eds.) Local Knowledge and Wisdom in Higher Education; Pergamon Elsevier: Oxford, UK, 2000.

14. Le Goff, J. Intellectuals in the Middle Ages; Basil Blackwell: Cambridge, UK; Massachusetts, MA, USA, 1993.

15. Brown, L. The New Shorter Oxford English Dictionary on Historical Principles; Clarendon Press: Oxford, UK, 1993.

16. Banerjee, D.K. The Ancient University of Nalanda. In Nalanda Past and Present; Upasak, C.S., Ed.; Nava Nalanda Mahavihara: Nalanda, India, 1977; pp. 1-25.

17. Krishnan, G.P. On the Nalanda Trail: Buddhism in India, China, and Southeast Asia; Asian Civilisations Museum: Singapore, 2008.

18. Ānandajoti Bhikkhu. Chinese pilgrims to Central Asia, India and SE Asia. Anc. Buddh. Texts 2013. Available online: https: //www.ancient-buddhist-texts.net/Maps/Silk-Routes/Chinese-Pilgrims.htm (accessed on 30 July 2021).

19. Hwui-Li, S.; Beal, S. The Life of Hiuen-Tsiang; Kegan Paul, Trench, Trubner \& Co. Reprinted by Facsimile Publisher; India for Gyan Books: Delhi, India, 1911.

20. Xuanzang. Si-Yu-Ki: Buddhist Records of the Western World; Kegan Paul, Trench, Trubner \& Co. Reprinted by Facsimile Publisher; India for Gyan Books: Delhi, India, 1906.

21. UNESCO. Role of Higher Education in Promoting Education For All; United Nations Educational, Scientific, and Cultural Organization (UNESCO): Bangkok, Thailand, 1992.

22. Comte, A.; Martineau, H. The Positive Philosophy of Auguste Comte; D. Appleton: New York, NY, USA, 1853.

23. Rogers, C. On Becoming a Person; Houghton Mifflin Co.: Boston, MA, USA, 1961.

24. Sternberg, R.J. Wisdom: Its Nature, Origins and Development; Cambridge University Press: Cambridge, UK, 1990.

25. Sternberg, R.; Glück, J. (Eds.) The Cambridge Handbook of Wisdom; Cambridge University Press: Cambridge, UK, 2019. [CrossRef]

26. Maxwell, N. Our Fundamental Problem: A Revolutionary Approach to Philosophy; McGill-Queens University Press: Kingston, ON, Canada, 2020.

27. Maxwell, N. The World Crisis—And What to Do about It: A Revolution for Thought and Action; World Scientific: Singapore, 2021.

28. Maxwell, N. From Knowledge to Wisdom: A Revolution in the Aims and Methods of Science; Basil Blackwell: Oxford, UK, 1984.

29. Maxwell, N. How Universities Can Help Create a Wiser World: The Urgent Need for an Academic Revolution; Imprint Academic: Exeter, UK, 2014.

30. Maxwell, N. The Metaphysics of Science and Aim-Oriented Empiricism: A Revolution for Science and Philosophy; Springer: New York, NY, USA, 2018.

31. Horkheimer, M.; Adorno, T.W. Dialectic of Enlightenment; Continuum: New York, NY, USA, 1982.

32. Bhaskar, R. Scientific Realism and Human Emancipation; Verso: London, UK, 1986.

33. Ma Rhea, Z. Unthinking the 200-year-old colonial mindset: Indigenist perspectives on leading and managing Indigenous Education. Int. Educ. J. Comp. Perspect. 2015, 14, 90-100.

34. Ma Rhea, Z.; Teasdale, G.R. (Eds.) A Dialogue between the Global and the Local. In Local Knowledge and Wisdom in Higher Education; Pergamon Elsevier: Oxford, UK, 2000; pp. 1-14.

35. Scheler, M. On the Positivistic Philosophy of the History of Knowledge and its Law of Three Stages. In The Sociology of Knowledge: A Reader; Curtis, J.E., Petras, J.W., Eds.; Gerald Duckworth and Co. Ltd: London, UK, 1963; pp. 161-169.

36. Taylor, A.; Pacini-Ketchabaw, V. Learning with children, ants, and worms in the Anthropocene: Towards a com-mon world pedagogy of multispecies vulnerability. Pedagog. Cult. Soc. 2015, 23, 507-529. [CrossRef]

37. Brundtland, G.H. Our Common Future (The Brundtland-Report); World Commission on Environment and Development: Oxford, UK, 1987.

38. Ma Rhea, Z. Universities and Wise Futures. Ph.D. Thesis, The Flinders University of South Australia, Adelaide, Australia, 1996. 
39. Ma Rhea, Z. Higher Education for a Wise Life: Wisdom Traditions and the Modern University. In Multicultural Knowledge and the University; Alvares, C., Ed.; India International Multiversity and Citizens International: Pune, India; Penang, Malaysia, 2014.

40. Ma Rhea, Z. Wisdom, Knowledge, and the Postmodern University in Thailand; Palgrave MacMillan: London, UK, 2017.

41. Toffler, A. Future Shock; Pan Books: London, UK, 1971.

42. Clarke, J. Oriental Enlightenment: An Encounter between Asian and Western Thought; Routledge: London, UK; New York, NY, USA, 1997.

43. Dore, R. The Diploma Disease: Education, Qualification, and Development; Allen and Unwin: London, UK, 1976.

44. Smith, D.S. Teaching as the Practice of Wisdom; Bloomsbury: London, UK, 2014.

45. Kane, R. Ethics and the Quest for Wisdom; Cambridge University Press: Cambridge, UK, 2010.

46. Ardelt, M. Empirical Assessment of a Three-Dimensional Wisdom Scale. Res. Aging 2003, 25, 275-324. [CrossRef]

47. Ardelt, M. Wisdom as Expert Knowledge System: A Critical Review of a Contemporary Operationalization of an Ancient Concept. Hum. Dev. 2004, 47, 257-285. [CrossRef]

48. Sternberg, R.J. (Ed.) Wisdom and Its Relations to Intelligence and Creativity. In Wisdom: Its Nature, Origins and Development; Cambridge University Press: Cambridge, UK, 1990; pp. 142-159.

49. Sternberg, R.J.; Jordan, J. A Handbook of Wisdom: Psychological Perspectives; Cambridge University: Cambridge, UK; New York, NY, USA, 2005.

50. Hattam, R. Socially-engaged Buddhism as a provocation for critical pedagogy in unsettling times. Cross-Cult. Stud. Curric. 2008, 109-136.

51. Steel, S. The Pursuit of Wisdom and Happiness in Education Historical Sources and Contemplative Practices; State University of New York Press: Albany, NY, USA, 2014.

52. Ferrari, M.; Westrate, N.M. The Scientific Study of Personal Wisdom; Springer: Dordrecht, The Netherlands, 2013.

53. Maxwell, N. How Wisdom Can Help Solve Global Problems. In Applying Wisdom to Contemporary World Problems; Sternberg, R.J., Nusbaum, H.C., Glück, J., Eds.; Palgrave Macmillan: London, UK, 2019.

54. Maxwell, N. The Urgent Need for Social Wisdom. In The Cambridge Handbook of Wisdom; Sternberg, R., Gluck, J., Eds.; Cambridge University Press: Cambridge, UK, 2019.

55. Maxwell, N. How Universities Have Betrayed Reason and Humanity-And What's to Be Done About It. Front. Sustain. 2021, 2. [CrossRef]

56. Beare, H.; Slaughter, R. Education For The Twenty-First Century; Routledge: London, UK; New York, NY, USA, 1993.

57. Semetsky, I.; Delpech-Ramey, J.A. Educating gnosis/making a difference. Policy Futures Educ. 2011, 9, 518-527. [CrossRef]

58. Furman, C. Descriptive inquiry: Cultivating practical wisdom with teachers. Teach. Teach. 2018, 24, 559-570. [CrossRef]

59. Lunenberg, M.; Korthagen, F. Experience, theory, and practical wisdom in teaching and teacher education. Teach. Teach. 2009, 15, 225-240. [CrossRef]

60. Kraft, K. Inner Peace, World Peace: Essays on Buddhism and Nonviolence; State University of New York Press: Albany, NY, USA, 1992.

61. Lombardo. The Future Evolution of Consciousness. World Futures Rev. 2014, 6, 322-335. [CrossRef]

62. Macdonald, C. Toward Wisdom: Finding Our Way to Inner Peace, Love E Happiness; Hounslow Press: Toronto, ON, Canada, 1993.

63. Nylander, C. Why and How to Upgrade Human Collective Wisdom; Lunds Universitet: Lund, Sweden, 2015. Available online: https:/ / www.academia.edu/21541883/Why_and_How_to_Upgrade_Human_Collective_Wisdom_feb_2016 (accessed on 30 July 2021).

64. Grossmann, I.; Kung, F.Y.H. Wisdom and Culture. In Handbook of Cultural Psychology, 2nd ed.; Kitayama, S., Cohen, D., Eds.; Guilford Press: New York, NY, USA, 2019.

65. Habermas, J. The Philosophical Discourse of Modernity; Polity Press: Cambridge, UK, 1987.

66. Toffler, A. The Futurists; Random House: New York, NY, USA, 1972.

67. Toffler, A. Learning for Tomorrow: The Role of the Future in Education; Vintage Books: New York, NY, USA, 1974.

68. Ma Rhea, Z. Mindful Teaching: Laying the Dharma Foundations for Buddhist Education in Australia. Int. Educ. J. Comp. Perspect. 2012, 11, 35-51.

69. Ma Rhea, Z. Buddhist pedagogy in teacher education: Cultivating wisdom by skilful means. Asia-Pac. J. Teach. Educ. 2017, 1. [CrossRef]

70. Cohen, L.; Manion, L. Research Methods in Education, 4th ed.; Routledge: London, UK, 1994.

71. Merriam, S.B. Qualitative Research and Case Study Applications in Education; Jossey-Bass: San Francisco, CA, USA, 1998.

72. Miles, M.B.; Huberman, A.M. Qualitative Data Analysis: An Expanded Sourcebook, 2nd ed.; Sage Publications: Thousand Oaks, CA, USA, 1994.

73. Silverman, D. Doing Qualitative Research: A Practical Handbook; Sage: Thousand Oaks, CA, USA, 2000.

74. Strauss, A.; Corbin, J. Basics of Qualitative Research: Grounded Theory Procedures and Techniques; Sage Publications: Newbury Park, CA, USA, 1990.

75. Stake, R.E. Identification of the Case. In Handbook of Qualitative Research; Denzin, N.K., Lincoln, Y.S., Eds.; Sage: Thousand Oaks, CA, USA, 1994; pp. 236-247.

76. Stake, R.E. The Art of Case Study Research; Sage: Thousand Oaks, CA, USA, 1995.

77. Tellis, W.M. Application of a Case Study Methodology. Qual. Rep. 1997, 3, 1-19. [CrossRef]

78. Yin, R.K. Case Study Research: Design and Methods, 4th ed.; Sage Publications: Thousand Oaks, CA, USA, 2009. 
79. Mace, R.; Pagel, M.; Bowen, J.R.; Gupta, B.K.D.; Otterbein, K.F.; Ridley, M.; Schweizer, T.; Voland, E. The Comparative Method in Anthropology [and Comments and Reply]. Curr. Anthropol. 1994, 35, 549-564. [CrossRef]

80. Naroll, R. Two Solutions to Galton's Problem. Philos. Sci. 1961, 28, 5-39. [CrossRef]

81. Hongladarom, K. Evidentials in Tibetan: A Dialogic Study in the Interplay between Form and Meaning; Indiana University: Indiana, IN, USA, 1993.

82. Bakhtin, M.M. The Dialogic Imagination; University of Texas Press: Austin, TX, USA, 1981.

83. Bakhtin, M.M. Speech Genres And Other Late Essays; University of Texas Press: Austin, TX, USA, 1986.

84. Habermas, J. The Theory of Communicative Action; Beacon Press: Boston, MA, USA, 1984.

85. Besley, T.; Peters, M.A. Intercultural understanding, ethnocentrism and western forms of dialogue. Anal. Metaphys. Ics 2011, 10, 81-100.

86. Vološinov, V.N. Marxism and the Philosophy of Language; Harvard University Press: Cambridge, MA, USA, 1929.

87. Mills, J.H.; Thurlow, A.; Mills, A.J. Making sense of sensemaking: The critical sensemaking approach. Qual. Res. Organ. Manag. Int. J. 2010, 5, 182-195. [CrossRef]

88. Ma Rhea, Z. The Economy of Ideas: Colonial Gift and Postcolonial Product. In Relocating Postcoloniality; Quayson, A., Goldberg, D.T., Eds.; Blackwells: London, UK, 2002; pp. 205-216.

89. Battiste, M.; Bell, L.; Findlay, L.M. Decolonizing education in Canadian universities: An interdisciplinary, international, indigenous research project. Can. J. Nativ. Educ. 2002, 26, 82-95.

90. Mbembe, A.J. Decolonizing the university: New directions. Arts Humanit. High. Educ. 2016, 15. [CrossRef]

91. Thaman, K.H. Decolonizing Pacific Studies: Indigenous Perspectives, Knowledge, and Wisdom in Higher Education. Contemp. Pac. SPRING 2003, 15, 1-17.

92. Finfgeld, D.L. Metasynthesis: The State of the Art-So Far. Qual. Health Res. 2003, 13, 893-904. [CrossRef]

93. Finfgeld-Connett, D. A Guide to Qualitative Meta-Synthesis; Routledge: New York, NY, USA, 2018.

94. Poser, C.; Guenther, E.; Orlitzky, M. Shades of green: Using computer-aided qualitative data analysis to explore different aspects of corporate environmental performance. Z. Plan. Unternehm. 2012, 22, 413-450. [CrossRef]

95. Smith, A.E.; Humphreys, M.S. Evaluation of unsupervised semantic mapping of natural language with Leximan-cer concept mapping. Behav. Res. Methods 2006, 38, 262. [CrossRef]

96. Smith, A.E.; Leximancer. Leximancer User Guide 4.5. Available online: https://info.leximancer.com/tutorial-guides (accessed on 30 July 2021).

97. Csikszentmihalyi, M.; Rathunde, K. Psychology of Wisdom: Evolutionary Interpretation. In Wisdom: Its Nature, Origin, and Development; Sternberg, R.J., Ed.; Cambridge University Press: Cambridge, UK, 1990; pp. 212-229.

98. Trowbridge, R.H. The Scientific Approach to Wisdom; Union Institute \& University: Cincinnati, OH, USA, 2005.

99. Bawany, N.S.; Nouman, N. A Step towards Better Understanding and Development of University Ontology in Education Domain. Res. J. Recent Sci. 2013, 2, 57-60.

100. Stancin, K.; Poscic, P.; Jaksic, D. Ontologies in educatio-State of the art. Educ. Inf. Technol. 2020, 25, 5301-5320. [CrossRef]

101. Diamond, Z.M. Gautama Buddha: Educating for Wisdom; Springer: Singapore, 2021. [CrossRef]

102. Sternberg, R.; Hagen, E. Teaching for Wisdom. In The Cambridge Handbook of Wisdom (Cambridge Handbooks in Psychology); Sternberg, R.J., Glück, J., Eds.; Cambridge University Press: Cambridge, UK, 2019; pp. 372-406. [CrossRef]

103. OED Online. Information; Oxford University Press: Oxford, UK, 2021. Available online: www.oed.com/view/Entry/95568 (accessed on 30 July 2021).

104. OED Online. Knowledge; Oxford University Press: Oxford, UK, 2021. Available online: www.oed.com/view/Entry/104170 (accessed on 30 July 2021).

105. Maina, F. Culturally relevant pedagogy: First Nations education in Canada. Can. J. Nativ. Stud. 1997, 17, $293-314$.

106. OED Online. Wisdom; Oxford University Press: Oxford, UK, 2021. Available online: www.oed.com/view/Entry/229491 (accessed on 30 July 2021).

107. Battiste, M. Indigenous Knowledge and Pedagogy in First Nations Education: A Literature Review with Recommendations; Apamuwek Institute: Ottawa, ON, Canada, 2002. Available online: https://www.afn.ca/uploads/files/education/24._2002_oct_marie_ battiste_indigenousknowledgeandpedagogy_lit_review_for_min_working_group.pdf (accessed on 30 July 2021).

108. Sternberg, R.J. A balance theory of wisdom. Rev. Gen. Psychol. 1998, 2, 347-365. [CrossRef]

109. Sternberg, R.J. Why Schools Should Teach for Wisdom: The Balance Theory of Wisdom in Educational Settings. Educ. Psychol. 2001, 36, 227-246. [CrossRef]

110. Kitchener, K.S.; Brenner, H.G. Wisdom and Reflective Judgement: Knowing in the Face of Uncertainty. In Wisdom: Its Nature, Origin, and Development; Sternberg, R.J., Ed.; Cambridge University Press: Cambridge, UK, 1990; pp. $212-229$.

111. Conze, E. The Way of Wisdom; Buddhist Publication Society: Kandy, Sri Lanka, 1980.

112. Takahashi, M. Relationship between Wisdom and Spirituality: An Expanded Theoretical Model with Mysticism and Gerotranscendence. In The Cambridge Handbook of Wisdom (Cambridge Handbooks in Psychology); Sternberg, R., Glück, J., Eds.; Cambridge University Press: Cambridge, UK, 2019; pp. 626-646. [CrossRef]

113. Habermas, J. Postmetaphysical Essays; MIT Press: London, UK; Cambridge, MA, USA, 1992. 
114. Ma Rhea, Z. Contemporary Knowledge Production and Reproduction in Thai Universities: Processes of Adaptive Balancing. In Local Knowledge and Wisdom in Higher Education; Teasdale, G.R., Rhea, Z.M., Eds.; Pergamon Elsevier: London, UK, 2000; pp. 209-235.

115. Ma Rhea, Z. The Implications of Changing Manifestations of Wisdom and Knowledge for Higher Education in Thailand. In Proceedings of the 9th World Conference of Comparative Education, Sydney, Australia, 1-6 July 1996.

116. Scheler, M. The Sociology of Knowledge: Formal Problems. In The Sociology of Knowledge: A Reader; Curtis, J.E., Petras, J.W., Eds.; Gerald Duckworth and Co. Ltd: London, UK, 1960; pp. 170-186.

117. Ardelt, M. Wisdom and Well-Being. In The Cambridge Handbook of Wisdom (Cambridge Handbooks in Psychology); Sternberg, R., Glück, J., Eds.; Cambridge University Press: Cambridge, UK, 2019; pp. 602-625. [CrossRef]

118. Beck, F.A. Traditional Elements in the Pedagogy of Socrates. Quad. Urbinati Cult. Class. 1986, 22, 107-129. [CrossRef]

119. Carpenter, W.B. Principles of Mental Physiology: In with Their Applications to The Training and Discipline of the Mind and the Study of Its Morbid Conditions; HS King \& Company: London, UK, 1875.

120. Cheng, K.M. Pedagogy: East and West, then and now. J. Curric. Stud. 2011, 43, 591-599. [CrossRef]

121. Cheng, L.; Xu, N. The complexity of Chinese pedagogic discourse. J. Curric. Stud. 2011, 43, 606-614. [CrossRef]

122. Edwards, R.G.T. Clement's Gnostic Interpretation of the Old Testament: Divine Pedagogy as the Basis for Clement of Alexandria's Biblical Interpretation; University of St. Michael's College: Toronto, ON, Canada, 2014.

123. Ellis, T.I. Toward a Gaian Humanistic Pedagogy: Teaching Cultures as Complex Adaptive Systems. Int. J. Humanit. 2007, 4, 57-66. [CrossRef]

124. Graham, D.W. Empedocles and Anaxagoras: Responses to Parmenides. In Cambridge Companion to Early Greek Philosophy; Long, A.A., Ed.; Cambridge University Press: Cambridge, UK, 1999; pp. 159-180.

125. Jianwei, Z. Different images of knowledge and perspectives of pedagogy in Confucius and Socrates. Complicity $2012,9,75$. [CrossRef]

126. Sabki, A.I.A.; Hardaker, G. The madrasah concept of Islamic pedagogy. Educ. Rev. 2013, 65, 342-356. [CrossRef]

127. Simms, R. Form and Meaning in the Sehtar Pedagogy of a Persian Sufi; Cambridge University Press: Cambridge, UK, 1992.

128. Smith, T.W. Revaluing Ethics: Aristotle's Dialectical Pedagogy; SUNY Press: Albany, NY, USA, 2001.

129. Wei, J. Teaching Method of an Enlightened Buddha and Educational System of Humanistic Buddhism. Hsi Lai J. Humanist. Buddhism 2003, 4, 306-318.

130. Young, R.D. Evagrius the Iconographer: Monastic pedagogy in the Gnostikos. J. Early Christ. Stud. 2001, 9, 53-71. [CrossRef]

131. Zongjie, W.; Chunyan, H. Pedagogy Toward Diversity: Historicizing the Present. In Systems of Reason and the Politics of Schooling: School Reform and Sciences of Education in the Tradition of Thomas S. Popkewitz; Pereyra, M., Franklin, B., Eds.; Routledge: London, UK, 2014.

132. Bauman, Z. Postmodern Ethics; Blackwell: Oxford, UK, 1993.

133. Dewey, J. Human Nature and Conduct: An Introduction to Social Psychology; Holt: New York, NY, USA, 1922.

134. Dewey, J. Theory of Valuation; The University of Chicago Press: Chicago, IL, USA, 1939.

135. Plato. Theaetetus; Macmillan: New York, NY, USA, 1986.

136. William of Ockham. Opera Philosophica et Theologica: Ad Fidem Codicum Manuscriptorum Edita; St. Bonaventure University Press: St Bonaventure, NY, USA, 1987.

137. Descartes, R. Meditations on First Philosophy; Dancing Unicorn Books: Lanham, MD, USA, 2019.

138. Aristotle; Bostock, D. Aristotle Metaphysics: Oxford; Clarendon Press: Oxford, UK, 1994.

139. Lorhard, J.; Bedekerus, F.G.; Johannes, M.F.G.; Fridericus, F.G.; Frisius, J.J.; Coler, J.F.; Lorhardus, J.; Straub, G. Ogdoas Scholastica: Continens Diapraphen Typicam Artium Grammatices Latinae. Grammatices Graeca. Logices. Rheto-Rices. Astronomices. Ethices. Physices. Metaphysices, seu Ontologiae; Universitats und Landesbibliothek Sachsen-Anhalt: Halle, Germany, 1606.

140. Wolff, C.; Centre Traditio Litterarum Occidentalium; Firm, B. Philosophia Prima Sive Ontologia Methodo Scientifica Pertractata Qua Omnis Cognitionis Humanae Principia Continentur; Brepols Publishers: Turnhout, Belgium, 2010.

141. Decock, L.; Horsten, L. Quine: Naturalized Epistemology, Perceptual Knowledge and Ontology; Rodopi: Amsterdam, The Netherlands, 2000.

142. Zinn, W.V. Phenomena and Noumena; Vantage Press: New York, NY, USA, 1984.

143. Althof, W.; Berkowitz, M.W. Moral education and character education: Their relationship and roles in citizenship education. J. Moral Educ. 2006, 35, 495-518. [CrossRef]

144. Cooke, S.; Carr, D. Virtue, Practical Wisdom and Character in Teaching. Br. J. Educ. Stud. 2014, 62, 91-110. [CrossRef]

145. Csikszentmihalyi, M.; Nakamura, J. The role of emotions in the development of wisdom. In Applications of Flow in Human Development and Education; Springer: Dordrecht, The Netherlands, 2014; pp. 99-116.

146. Giroux, H.A.; Purpel, D.E. The Hidden Curriculum and Moral Education: Deception or Discovery? McCutchan Pub. Corp: Berkeley, CA, USA, 1983.

147. Kristjánsson, K. Aristotelian Character Education; Routledge: London, UK, 2015.

148. Malaska, P. Threefold Harmony and Societal Transformation. In Transition to A Global Society; Bushrui, S., Ayman, I., Laszlo, E., Eds.; Oneworld Publications Limited: Oxford, UK, 1993; pp. 43-51.

149. Ayya Khema, B. Being Nobody, Going Nowhere: Meditations On The Buddhist Path; Wisdom Publications: Boston, MA, USA, 1987; p. 224.

150. Ayya Khema, B. When the Iron Eagle Flies: Buddhism for The West; Arkana: London, UK, 1991. 
151. Buddhadasa Bhikku. Handbook For Mankind; Sublime Life Mission: Bangkok, Thailand, 1956.

152. Buddhadasa Bhikku. Dhammic Socialism; Thai Inter-Religious Commission for Development: Bangkok, Thailand, 1986.

153. Buddhadasa Bhikku. Buddha-Dhamma For Students; The Dhamma Study and Practice Group: Bangkok, Thailand, 1988.

154. Buddhadasa Bhikku. Key To Natural Truth; The Dhamma Study and Practice Group: Bangkok, Thailand, 1989.

155. Buddhaghosa. The Path of Purification (Visuddhimagga); Corporate Body of the Buddha Educational Foundation: Bangkok, Thailand, 1999.

156. Nyanatiloka, M. The Word of the Buddha, 16th ed.; Buddhist Publication Society: Kandy, Ceylon, 1981.

157. Nyanatiloka, M. Path to Deliverance, 4th ed.; Buddhist Publication Society: Kandy, Sri Lanka, 1982.

158. Macbeth, J. Moon over Water; Gateway Books: Bath, UK, 1991.

159. Ferrari, M.; Kim, J. Educating for Wisdom. In The Cambridge Handbook of Wisdom (Cambridge Handbooks in Psychology); Glück, R.S.J., Ed.; Cambridge University Press: Cambridge, UK, 2019; pp. 347-371. [CrossRef]

160. Harvey, D. The Condition of Postmodernity; Basil Blackwell: Oxford, UK, 1989.

161. Giddens, A. The Consequences of Modernity; Polity Press: Cambridge, UK, 1990.

162. Kegan, R. In Over Our Heads: The Mental Demands of Modern Life; Harvard University Press: Cambridge, UK, 1994.

163. Biermann, S.; Townsend-Cross, M. Indigenous Pedagogy as a Force for Change. Aust. J. Indig. Educ. 2008, 37, 146-154. [CrossRef]

164. Cataldi, L. Women Who Live on The Ground; Penguin Books: Sydney, Australia, 1990.

165. Sivaraksa, S. A Buddhist Vision for. In Renewing Society; Thai Inter-Religious Commission for Development: Bangkok, Thailand, 1994. 